\title{
In Vivo Evidence for Voltage-Gated Sodium Channel Expression in Carcinomas and Potentiation of Metastasis
}

\author{
Mustafa B. A. Djamgoz ${ }^{1, *}$, Scott P. Fraser ${ }^{1}$ and William J. Brackenbury ${ }^{2}$ (D) \\ 1 Department of Life Sciences, Neuroscience Solutions to Cancer Research Group, Imperial College London, \\ South Kensington Campus, London SW7 2AZ, UK; s.p.fraser@imperial.ac.uk \\ 2 Department of Biology and York Biomedical Research Institute, University of York, Heslington, \\ York YO10 5DD, UK; william.brackenbury@york.ac.uk \\ * Correspondence: m.djamgoz@imperial.ac.uk; Tel.: +44-207-594-5370
}

Received: 16 August 2019; Accepted: 10 October 2019; Published: 28 October 2019

\begin{abstract}
A wide body of evidence suggests that voltage-gated sodium channels (VGSCs) are expressed de novo in several human carcinomas where channel activity promotes a variety of cellular behaviours integral to the metastatic cascade. These include directional motility (including galvanotaxis), $\mathrm{pH}$ balance, extracellular proteolysis, and invasion. Contrary to the substantial in vitro data, however, evidence for VGSC involvement in the cancer process in vivo is limited. Here, we critically assess, for the first time, the available in vivo evidence, hierarchically from mRNA level to emerging clinical aspects, including protein-level studies, electrolyte content, animal tests, and clinical imaging. The evidence strongly suggests that different VGSC subtypes (mainly Nav1.5 and Nav1.7) are expressed de novo in human carcinoma tissues and generally parallel the situation in vitro. Consistent with this, tissue electrolyte (sodium) levels, quantified by clinical imaging, are significantly higher in cancer vs. matched non-cancer tissues. These are early events in the acquisition of metastatic potential by the cancer cells. Taken together, the multi-faceted evidence suggests that the VGSC expression has clinical (diagnostic and therapeutic) potential as a prognostic marker, as well as an anti-metastatic target. The distinct advantages offered by the VGSC include especially (1) its embryonic nature, demonstrated most clearly for the predominant neonatal Nav1.5 expression in breast and colon cancer, and (2) the specifically druggable persistent current that VGSCs develop under hypoxic conditions, as in growing tumours, which promotes invasiveness and metastasis.
\end{abstract}

Keywords: metastasis; voltage-gated sodium channel; embryonic splice; imaging; electrolytes; xenografts; epidemiology

\section{Introduction}

Cancer is a major killer in the modern world with one in two men and one in three women expected to be diagnosed with some kind of cancer during their lifetime. Some 9.6 million cancer-related deaths were estimated globally in 2018 [1,2]. The current statistics are expected to rise by more than $70 \%$ over the next two decades, reaching 17 million annual deaths by 2030 [1]. Causes include longevity, as well as unhealthy diets and lifestyles, leading to obesity and type-2 diabetes, which are interrelated and promote cancer incidence. Although great progress has been made in clinical management of cancer, many problems nonetheless remain. These include uncertainties in diagnosis, limited effectiveness, and undesirable side effects of major treatment modalities such as chemotherapy, radiotherapy, and biological therapies. Furthermore, cancer treatment, especially novel therapies such as immunotherapy, can be very costly. In conclusion, there is a great unmet need in cancer management. In this regard, ion channels have emerged in the last two decades as promising new targets [3-6]. It is 
likely that cancer cells/tissues express as many types of ion channels as the brain, the classic home of ion channels, and these contribute to different components and stages of the dynamic process of cancer development and progression, as well as response to therapy.

We have placed particular emphasis on voltage-gated ion channels (VGICs) due to the profound impact upon cellular processes of membrane potentials (equivalent to some 10,000,000 V/m). With regard to metastasis, the main cause of death from cancer, a substantial body of evidence suggests voltage-gated sodium channels (VGSCs) are expressed de novo in cells derived from a wide range of carcinomas. Specifically, invasive cancer cells with strong metastatic ability have been shown to express functional VGSCs. The initial discovery was made in rat prostate cancer cells and then confirmed in humans $[7,8]$. Subsequently, several other carcinoma cell lines were also shown to express functional VGSC(s). These include cancers of breast, prostate, colon, lung, stomach, cervix, ovary, and skin (see Table 1). Interestingly, of the nine functional subtypes of VGSC, in these carcinomas, two appeared as the most prevalent-Nav1.5 and Nav1.7 (Table 1).

Table 1. Voltage-gated sodium channel (VGSC) subtype expression in human carcinomas.

\begin{tabular}{|c|c|c|c|}
\hline Carcinoma & VGSC Subtype(s) & Comment(s) & Reference(s) \\
\hline Breast & $\begin{array}{c}\mathrm{nNav1.5} \\
\text { (and (n)Nav1.7) }\end{array}$ & $\begin{array}{l}\text { Dominant at mRNA level and functional contribution to } \\
\text { invasiveness/metastasis verified in vitro and in vivo }\end{array}$ & {$[9-12]$} \\
\hline Colon & nNav1.5 & $\begin{array}{l}\text { Dominant at mRNA level and expressed early in invasiveness; } \\
\text { functional contribution to invasiveness verified in vitro and } \\
\text { in vivo }\end{array}$ & [13-15] \\
\hline Prostate & $\begin{array}{l}\text { (n)Nav1.7 } \\
\text { (and Nav1.6) }\end{array}$ & $\begin{array}{l}\text { Dominant at mRNA level; specific functional contribution to } \\
\text { invasiveness tested using peptide toxins }\end{array}$ & {$[8,16-18]$} \\
\hline $\begin{array}{l}\text { Non-small cell lung } \\
\text { carcinoma (NSCLC) }\end{array}$ & Nav1.7 & $\begin{array}{c}\text { Dominant at mRNA level; potentiation of invasiveness } \\
\text { demonstrated by use of siRNA }\end{array}$ & [19] \\
\hline Mesothelioma & $\begin{array}{l}\text { Nav1.2, Nav1.6, } \\
\text { and Nav1.7 }\end{array}$ & $\begin{array}{l}\text { VGSC activity shown to promote migration in vitro, but the } \\
\text { subtype(s) responsible not determined }\end{array}$ & [20] \\
\hline Cervical & (n)Nav1.6 & $\begin{array}{c}\text { Dominant at mRNA level; over-expression potentiated } \\
\text { invasiveness }\end{array}$ & {$[21,22]$} \\
\hline Stomach & Nav1.7 & $\begin{array}{l}\text { Dominant at mRNA level; silencing suppressed tumour growth in } \\
\text { mouse model in vivo }\end{array}$ & [23] \\
\hline Ovary & Nav1.5 & $\begin{array}{l}\text { Dominant at mRNA level; E3 antibody suppressed in vivo growth } \\
\text { and in vitro invasiveness }\end{array}$ & {$[24,25]$} \\
\hline Melanoma & Nav1.5 & $\begin{array}{l}\text { Expression induced membrane potential depolarization and } \\
\text { inhibited } \mathrm{Ca}^{2+} \text { uptake }\end{array}$ & [26] \\
\hline $\begin{array}{l}\text { Oral squamous cell } \\
\text { carcinoma }\end{array}$ & Nav1.5 & $\begin{array}{l}\text { siRNA confirmed in vitro potentiation of proliferation } \\
\text { and invasiveness }\end{array}$ & [27] \\
\hline Astrocytoma & nNav1.5 & $\begin{array}{l}\text { siRNA confirmed in vitro potentiation of proliferation } \\
\text { and invasiveness }\end{array}$ & [28] \\
\hline Neuroblastoma & nNav1.5 & $\begin{array}{c}\text { Where 'neonatal' Nav1.5 splicing was first described, but role in } \\
\text { cancer not investigated }\end{array}$ & [29] \\
\hline Endometrium & Nav1.7 & $\begin{array}{l}\text { Channel block attenuated in vitro cell invasion; expression was } \\
\text { associated (i) positively with tumour size and local lymph node } \\
\text { metastasis, and (ii) negatively with survival (5-10 years) }\end{array}$ & {$[30]$} \\
\hline \multicolumn{4}{|c|}{$\begin{array}{l}\text { Although different carcinomas express different subtype(s) of VGSC, two appear most common-Nav1.5 and Nav1.7. } \\
\text { Where studied, the channels were found to occur in 'neonatal' splice form (indicated by the prefix "n"). Although } \\
\text { brain tumours are not covered in this review, astrocytoma and neuroblastoma are included for completeness. } \\
\text { In most cases, the role of VGSC activity in promoting invasiveness was tested using tetrodotoxin (TTX). In addition, } \\
\text { some studies also demonstrated the role of the 'dominant' VGSC subtype by siRNA or antibody. Only exemplary } \\
\text { references are given. }\end{array}$} \\
\hline
\end{tabular}

Importantly, where studied, the VGSC upregulation was found to be accompanied by downregulation of outward (mainly $\mathrm{K}^{+}$) currents [7-9,20,31]. Such combination of VGICs would make membranes of strongly metastatic cancer cells potentially electrically 'excitable'. This was formulated as the "Celex Hypothesis", proposing that it is this membrane excitability that makes metastatic cells aggressive and hyperactive, leading to disruption of their surroundings [32,33]. Indeed, a recent study has shown that the strongly metastatic human prostate cancer PC-3 cells undergo spontaneous regenerative spike activity, although these were thought to be driven by $\mathrm{Ca}^{2+}[34]$. 
A further study extended this approach to ex vivo recording of electrical activity (local field potentials) associated with breast cancer cells implanted in the cortex of mice. Thus, it was shown that aberrant spontaneously-occurring spike events occurred within the intact tumour microenvironment [35].

As regards mechanisms, VGSCs can function in two distinct modes-conducting and non-conducting. In turn, the conducting mode can generate two kinetically distinct currents-transient $\left(\mathrm{I}_{\mathrm{NaT}}\right)$ and persistent $\left(\mathrm{I}_{\mathrm{NaP}}\right)$. The latter is promoted by hypoxia, well known to occur in growing tumours, and may be responsible for elevating the level of $\mathrm{Na}^{+}$in cancer tissues (see the section on 'tissue electrolytes'). Indeed, $\mathrm{I}_{\mathrm{NaP}}$ has been proposed as a major anti-metastatic target $[13,36]$. The non-conducting ('non-canonical') mode may involve the alpha or the beta subunit through protein-protein interactions and immunoglobulin-like cell adhesion effects, respectively. The latter may be mediated by beta subunits, which may also be expressed independently of alpha subunits. Regarding the alpha subunit, most evidence points to the sodium-hydrogen exchanger 1 (NHE1) as an interacting/downstream partner. Thus, VGSC-activated NHE1 can acidify the pericellular space, leading to extracellular proteolysis and promotion of invasiveness [37]. Subsequently, Src kinase and invadopodial activity were also demonstrated to be involved in the invasiveness [38].

In spite of the substantial in vitro evidence for functional VGSC expression in invasive cancer cells and the emerging mechanistic insights, however, work to determine in vivo relevance of the findings has been relatively sporadic [39]. Here, we assess, for the first time in depth, the available in vivo evidence hierarchically from tissue mRNA expression to whole-animal and clinical studies. The main emphasis is on carcinomas; haematological and brain cancers are beyond the scope of this review because their pathophysiology may be different.

\section{2. mRNA Level Studies}

Multiple VGSCs have been detected at mRNA level for individual human cancers. Fraser et al. (2005) described Nav1.5-1.7 transcripts in human breast cancer (BCa) biopsy tissues [9]. On the other hand, prostate cancer (PCa) biopsies were found to express Nav1.2/1.3/1.5-1.7/1.9 mRNAs [16]. Nav1.7 was dominant, consistent with VGSC currents recorded from strongly metastatic PC-3 cells being tetrodotoxin-sensitive (TTX-S) [8]. Human malignant pleural mesothelioma cells in primary culture expressed Nav1.6 and Nav1.7 mRNAs most consistently [20]. Human malignant cervical cancer cells from smear biopsies in primary culture expressed Nav1.2/1.4/1.6/1.7 mRNAs, with Nav1.6 being dominant [21,22].

Importantly, VGSC mRNA expression has been shown to correlate with disease progression in several carcinomas and, thus, may have prognostic implications. In human prostate biopsies the Nav1.7 mRNA level was significantly higher in (i) cancer vs. non-cancer (mainly 'benign prostatic hyperplasia'/BPH) tissues and (ii) high-grade (Gleason score $>6$ ) vs. low-grade tumours (Figure 1A,B) [16]. Receiver operating characteristic (ROC) analysis revealed that the Nav1.7 mRNA expression had sufficient specificity and selectivity to be considered a viable diagnostic biomarker for PCa (Figure 1C) [16]. In a later study, expression of Nav1.1-1.3, Nav1.5-1.7, and Nav1.9 mRNAs were found in normal prostate and Nav1.1-1.7 for BPH. Importantly, however, transcript levels of Nav1.6 and Nav1.7, respectively, were 6- and 27-fold higher in PCa compared with normal or BPH samples [40]. 
A
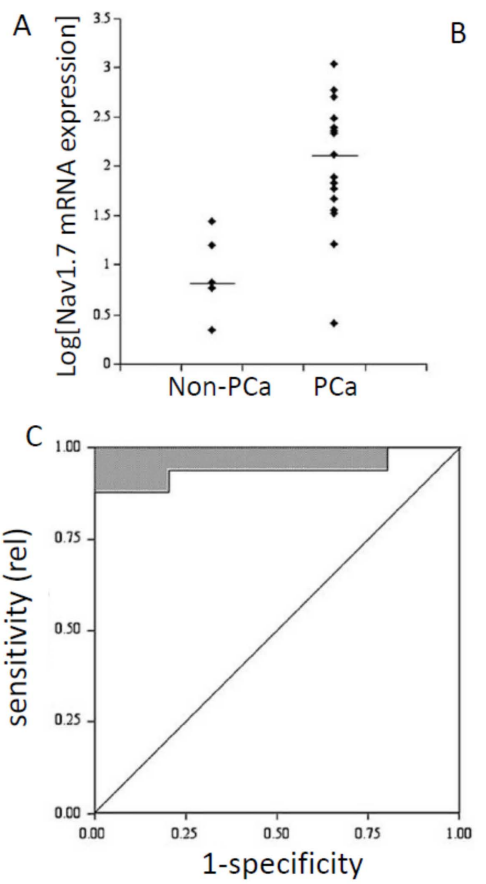

$B$

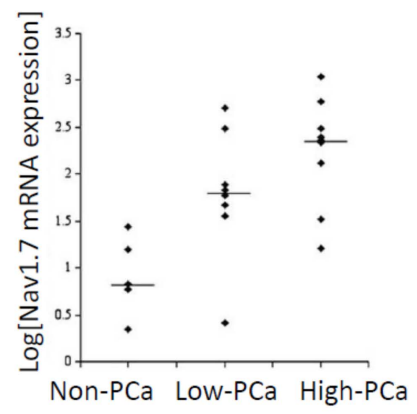

D

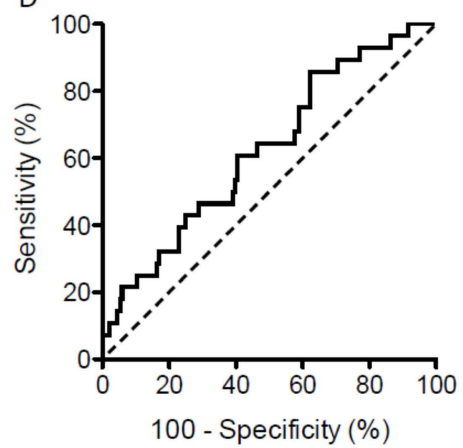

Figure 1. VGSC mRNA expression and associated 'receiver operator characteristics' of human prostate and breast cancers. (A-C) Data for human prostate cancer (PCa). Nav1.7 mRNA levels in non-PCa vs. PCa patient samples determined by real-time PCR. "Non-PCa" were mostly benign prostatic hyperplasia. Logarithmic plots of Nav1.7 expression levels normalized to beta-actin are shown. (A) Non-PCa vs. PCa. (B) Comparisons of non-PCa, low-grade PCa (Gleason grade < 6), and higher grade PCa (Gleason grade $>6$ ). Medians are shown as short horizontal lines in both (A) and (B). (C) "Receiver operator characteristics" (ROC) analysis showing the potential diagnostic efficacy of Nav1.7 mRNA expression in distinguishing non-PCa $(n=5)$ from PCa $(n=17)$. Efficacy is indicated by upper-left deviation from the non-discriminatory diagonal line. (D) ROC analysis as in (C) but for breast cancer $(n=181)$. Modified from [16] (A-C), and [41] (D).

In conclusion, most evidence suggests (i) that Nav1.7 is the dominant VGSC mRNA species in human PCa and (ii) that the expression/upregulation has diagnostic/prognostic potential.

For human BCa, initial comparative PCR studies on strongly metastatic (MDA-MB-231) cells with weakly/non-metastatic (MCF-7) cells revealed Nav1.5 mRNA to be (ca. 1800-fold) higher, consistent with the VGSC current in the former being TTX-resistant (TTX-R) [9]. A double-blind test on 20 patients revealed that the expression of Nav1.5 mRNA in breast biopsies was significantly directly correlated with the presence of metastasis in lymph nodes (LNMs) in $~ 75 \%$ of cases. There was no case of LNM without Nav1.5 expression. The remaining 25\% were Nav1.5-positive but LNM-negative, raising the possibility that the Nav1.5 expression in breast tissue had occurred but metastases had not yet developed, that is, that Nav1.5 expression is an early event in the acquisition of metastatic potential [9]. Consistent with this, an in silico study on colon cancer concluded that SCN5A (the gene encoding Nav1.5) expression was upstream of several canonical invasiveness-associated genes, including those for $\mathrm{Ca}^{2+}$ signalling, Wnt signalling, mitogen-activated protein (MAP) kinase, proteases, and membrane remodelling/secretion [14].

A further study also showed Nav1.5 mRNA to be significantly (3.6-fold) higher in invasive BCa compared to normal breast tissue [41]. Importantly, Nav1.5 mRNA expression was also significantly higher in patients (i) who died rather than survived the disease (Figure 2A), (ii) with disease recurrence vs. non-recurrence (Figure 2B), and (iii) whose survival was poorer (Figure 2C) [41]. As in the case of PCa, ROC analysis indicated Nav1.5 mRNA expression in human BCa to have sufficient specificity and selectivity to be considered a viable diagnostic biomarker (Figure 1D) [41]. 
A

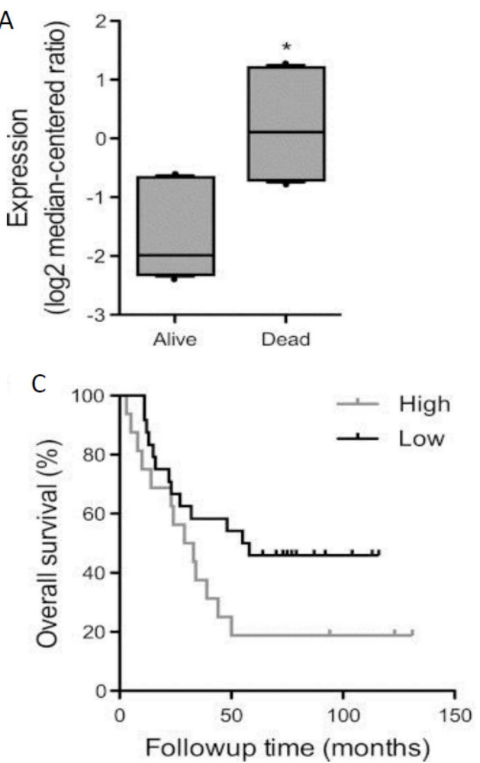

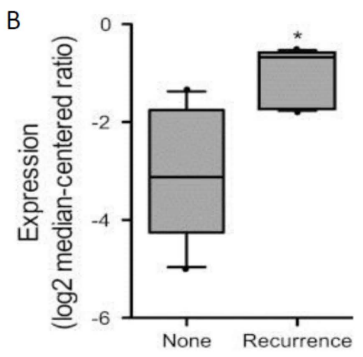

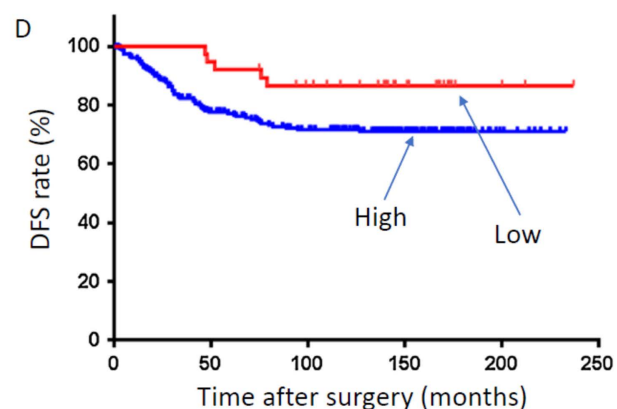

Figure 2. Positive associations between VGSC (Nav1.5) expression and clinical behaviour of breast and colon cancers. The channel is presumed to be 'neonatal' Nav1.5. (A) Patients who died of breast cancer expressed significantly more Nav1.5 mRNA than those who were alive. ${ }^{*}=p<0.05$. (B) Breast cancer patients whose cancer recurred expressed significantly more Nav1.5 mRNA than those who were still cancer-free. ${ }^{*}=p<0.05$. (C) Overall survival was significantly longer for breast cancer patients expressing low levels of Nav1.5 mRNA, compared with those with high levels of expression $(n=181)$. (D) Disease-free survival (DFS) of colon cancer patients in relation to Nav1.5 protein expression $(n=23$ and 183 for low- and high-expression, respectively; $p=0.032$ ). Time is for months after radical resection. Modified from [41] (A-C) and [42] (D).

In human cervical cancer biopsies, Nav1.6 mRNA levels were $\sim 40$-fold higher than in non-cancerous cervical tissues [22]. Similarly, the mRNA expression of a Nav1.7 splice-variant was 20-fold higher in cancer than normal tissue [22]. Interestingly, several different Nav1.6 mRNA splice variants (from Exon 18) that would encode non-functional protein were also identified in cervical tissue biopsies [43]. However, the variant $18 \mathrm{~A}$ encoded a functional protein and its expression correlated with cancer progression, being detected in only $58 \%$ of non-cancerous tissues, but $75 \%$ of neoplasia, and $100 \%$ of cervical cancer samples positive for human papilloma virus type 16. Subsequent work thus focused on Nav1.6 as the VGSC driving the invasiveness [43].

Although VGSC expression has not been studied in colorectal carcinoma (CRCa) tissues in detail at the mRNA level, cell-based studies suggested Nav1.5 expression to be predominant, consistent with the TTX-R nature of the VGSC currents $[14,15]$. Importantly, using three different siRNAs, Guzel et al. (2019) showed that Nav1.5 (specifically the neonatal splice variant, nNav1.5) was primarily responsible for the VGSC-dependent component of invasiveness [13]. Interestingly, in CRCa, a significantly lower level of Nav1.6 mRNA expression was found in tumour tissues compared with paired neighbouring non-cancerous tissues [44]. This difference was more pronounced for patients below the age of 45 and correlated significantly with gender, tumour grade, location, and histopathological classification [44]. At present, it is not clear if the Nav1.6 mRNA expression is translated to protein, especially as the VGSC currents are TTX-R, which would rule out Nav1.6 being functional. In conclusion, evidence favours $\mathrm{nNav1.5}$ as being primarily responsible for promoting the metastatic process in CRCa.

In human gastric cancer biopsy tissues, a detailed study by Xia et al. (2016) showed via real-time-PCR analyses that Nav1.7 (SCN9A) was the most highly expressed VGSC subtype [23]. An earlier study also found functional Nav1.5 expression in vitro, but this was not confirmed in vivo [45]. Finally, for human ovarian cancer, Nav1.1, 1.3-1.5, mRNA levels were significantly higher (ca. 10-fold for Nav1.5) in cancer cells compared with benign ovarian tumour or normal ovary [24]. It was Nav1.5 
mRNA expression, however, that was proposed to be increased at the transition from normal to benign and then to cancer, and was even higher in ovarian cancers with lymph node metastases than those without [24]. This brings up the possibility of an in vivo-in vitro mismatch, as Nav1.5 mRNA (which, if functionally expressed) would give rise to a TTX-R channel, whereas the predominant functional VGSC in the SKOV-3 ovarian cancer cell line is TTX-S [46].

Importantly, where studied, the predominant VGSC has been shown to be consistent with a developmentally regulated 'neonatal' splice form. This is most pronounced in Nav1.5, wherein the switch from the 3' ('adult') to the 5' ('neonatal') form of exon 6 generates a difference of 31 nucleotides [9]. This results in a change in seven amino acids in the extracellular loop of segments $3-4$ in domain 1 [9]. In particular, the amino acid at position 211 switches from a negatively charged aspartate in 'adult' to a positively charged lysine in 'neonatal', that is, a double charge change. Similar splicing for Nav1.6 and Nav1.7 would result in the 'homologous' aspartate switching to an arginine. Predominant nNav1.5 expression has been demonstrated most extensively in $\mathrm{BCa}$, including in human biopsies $[9,10]$. It also occurs in colon cancer, and possibly melanoma, astrocytoma, neuroblastoma, and ovarian cancer (Table 1). This 'oncofoetal' phenomenon is consistent with the dedifferentiated nature of cancer tissues.

From the available mRNA-level evidence, three main conclusions can be drawn. First, expression of VGSC mRNA(s) is significantly higher in cancer relative to comparable normal/non-cancerous tissues. Second, multiple VGSC mRNA transcripts occur in human cancers. Although one of these appears to be dominant in one condition, it is possible that dynamic changes occur during the progression of the disease and/or in response to therapy. Third, importantly, where studied, the mRNA expression has been found to be in 'neonatal' splice forms. This aspect has significant implications for the clinical applicability of VGSCs. Nevertheless, the presence of mRNA(s) does not guarantee protein expression (e.g., [47-49]). The in vivo evidence for VGSC protein expression in cancers is discussed in the following section.

\section{Protein Expression}

VGSC protein expression has been shown to occur in several cancers and correlates generally with disease progression/metastatic potential. Functional VGSC protein has been detected ex vivo. Primary cultures of cervical cancer epithelial cells were shown to express TTX-S VGSC currents [21]. Further work using Cn2, a Nav1.6-specific toxin, revealed activity of Nav1.6 channels in the plasma membrane of these cells [22]. Consistent with this, robust Nav1.6 immunoreactivity was detected in cervical cancer biopsies and primary cultures at levels much higher than normal cervical tissues, with expression widely distributed in both cytoplasm and plasma membrane [22]. Importantly, both TTX $(6 \mu \mathrm{M})$ and $\mathrm{Cn} 2(1 \mu \mathrm{M})$ reduced invasiveness of the primary cervical cancer cells by $\sim 20 \%$ [22]. Interestingly, immunohistochemistry also revealed Nav1.7 protein expression in cervical cancer biopsies, but its possible functional relevance was not studied. Similarly, a TTX-S VGSC current $\left(\mathrm{IC}_{50}=16 \mathrm{nM}\right)$ was detected in primary cultures of human malignant pleural mesothelioma cells, but not in normal mesothelial cells [20]. As in all other carcinomas studied, channel activity significantly enhanced the cells' motility [20]. Interestingly, in agreement with the Celex Hypothesis, the VGSC upregulation (de novo expression) was accompanied by a significant reduction in the amplitude of 'outward' voltage-gated $\mathrm{K}^{+}$current [20].

In human prostate biopsies and tissue microarrays, VGSC protein expression was found to be significantly higher in cancer vs. non-cancer (Figure 3D,E) [16,50]. A pan-VGSC antibody was used in these studies due to the unreliability of available antibodies for Nav1.7, the predominant VGSC subtype in PCa. However, no correlation was found between the intensity of the VGSC immunoreactivity and Gleason score (GS), as well as the level of prostate-specific antigen [50]. Expression was apparent in PCa cases with a GS of 7, often taken to be the transition to malignancy [51]. This is consistent, again, with VGSC upregulation being an early marker of metastatic progression, as has been suggested also for $\mathrm{BCa}$ [9] and colon cancer [14]. Interestingly, statistically significant association was found between Nav1.8 protein expression in human PCa and pathological stage, GS, and lymph node involvement [52]. 
However, the quality of the immunohistochemistry in this study is not clear because unexpected nuclear staining was apparent. Furthermore, possible in vivo-in vitro mismatch aside, Nav1.8 is a TTX-R VGSC, whereas human PCa cells express TTX-S channels (mainly Nav1.7), and anti-invasive/metastatic effects can be obtained with sub-micromolar concentrations of TTX $[8,53]$.
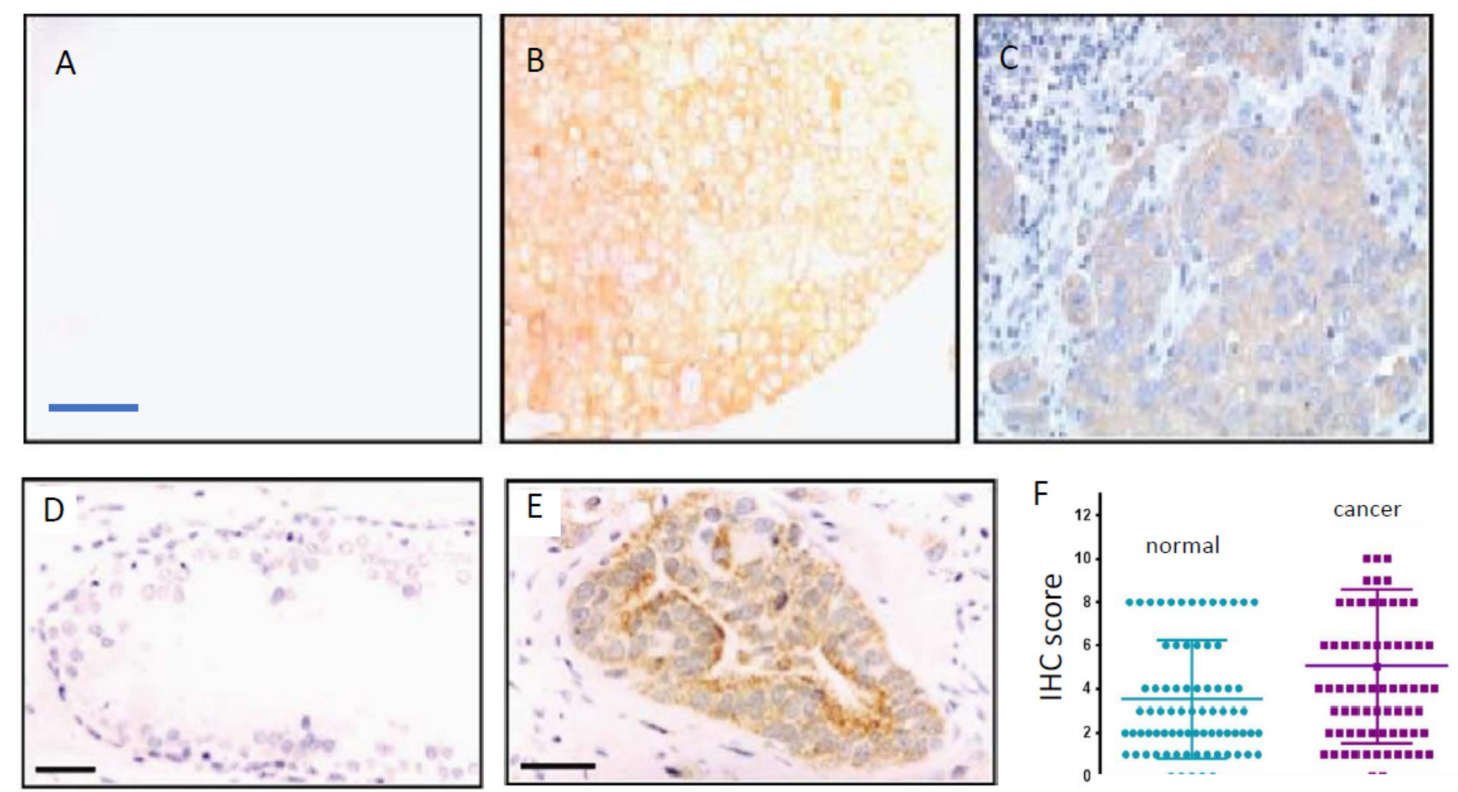

Figure 3. VGSC protein expression in breast, prostate, and colon cancers. VGSC alpha-subunit protein expression in human cancer biopsy tissue sections was determined by immunohistochemistry (IHC). (A-C) Typical immunostaining of human breast tissue with nNav1.5-specific polyclonal antibody (NESOpAb). Little staining was detected in normal human breast tissue, as illustrated in (A), whereas strong heterogeneous staining was detected in the corresponding image from breast cancer (B). Sections were also counterstained with haemotoxylin to confirm tissue integrity (C). Scale bar, shown in (A) is $50 \mu \mathrm{m}$ and is applicable also to (B) and (C). (D,E) Typical staining of human prostate tissue sections exhibiting morphological features of low-grade prostatic intraepithelial neoplasia (PIN) (D), and high-grade PIN (E). A pan-VGSC alpha-subunit antibody was used. Sections were also counterstained with haemotoxylin to confirm tissue integrity. Scale bar, $50 \mu \mathrm{m}$ is applicable to (D) and (E). (F) Quantitative data showing significantly higher level of Nav1.5 IHC staining of colon cancer compared with matched normal tissue $(p<0.001 ; n=78)$. Modified from [9] (A-C); [16] (D,E); and [42] (F).

In human ovarian cancer, western blot assays suggested that there was almost no Nav1.5 protein expression in normal ovary, but this was higher in cancer biopsy tissues [24]. Immunohistochemistry also revealed the expression of Nav1.5 protein in epithelial cells of ovarian cancer biopsies tissues to be much higher than normal ovary [24]. However, again, possible in vivo-in vitro mismatch aside, the suggested 'predominant' expression of Nav1.5 (a TTX-R channel) in ovarian cancer is at odds with the finding of a functional TTX-S channel in the SKOV-3 ovarian cancer cell line [46]. In summary, whilst it would appear that upregulated VGSC protein expression occurs in human ovarian cancer, more work is needed to elucidate the nature of the VGSC mRNA(s) and protein(s) expressed.

For small-cell lung carcinoma, an immunohistochemical study demonstrated VGSC protein upregulation in tumour tissue [54]. A later, more detailed study, which identified Nav1.7 mRNA as the dominant VGSC subtype in several non-small cell lung carcinoma (NSCLC) cell lines, confirmed that Nav1.7 protein expression was also markedly higher for tumour vs. normal lung tissue [19]. It was considered possible that increased Nav1.7 protein expression accompanied the transition from low- to high-grade tumours [19]. This study also demonstrated, albeit in vitro, that the pro-invasive effect of epidermal growth factor (EGF) was mediated largely through the VGSC (Nav1.7). If this observation can (i) be validated in an in vivo animal model and (ii) be demonstrated in human biopsies, for example, 
in the form of VGSC + EGF/EGF receptor (EGFR) co-localization, it could form the basis of a novel therapy of NSCLC, for example, combining an EGFR tyrosine kinase inhibitor with a VGSC blocker.

As described in Section 2 above, the alternative splicing of exon 6 results in the functional expression of a neonatal form of Nav1.5 in BCa cells $[9,10]$. The aspartate-to-lysine switch was shown to be responsible for key electrophysiological differences between the two splice variants and, thus, is likely to give rise to pharmacological differences that may be used therapeutically [55]. Importantly, the amino acid differences enabled the production and validation of a polyclonal antibody (“NESOpAb") with greater than two orders of magnitude blocking selectivity for nNav1.5 over 'adult' Nav1.5 [56].

In human BCa biopsy sections, the use of NESOpAb demonstrated that $n N a v 1.5$ protein expression was markedly upregulated, compared with normal breast tissues (Figure 3A-C) [9]. Densitometric analysis confirmed the difference to be highly significant as regards both the intensity and the extent of the staining [57]. The latter study also confirmed the lack of expression of nNav1.5 protein expression in a range of other normal human tissues [57]. Thus, nNav1.5 protein expression appears to be cancer-specific [57]. A separate study using an antibody that recognises both nNav1.5 and adult Nav1.5 showed a similar significant up-regulation in breast tumours compared with surrounding normal tissue [11].

In colon cancer, Nav1.5 protein expression has been demonstrated to be at levels significantly higher than matched normal tissues (Figure 3F) [14,42]. However, in line with the in vitro data, the predominant VGSC is considered to be nNav1.5 [13,58]. Indeed, a preliminary study using the NESOpAb antibody demonstrated significantly higher nNav1.5 protein levels for colon cancer biopsy tissues compared with matched mucosa (normal tissues) [58]. An early study had reported expression of a VGSC (unknown subtype) in normal colonic epithelial using a pan-VGSC antibody, but no comparison with cancer was made [59]. Expression was mostly restricted to the cytoplasm or luminal surfaces of the epithelial cells-the subcellular distribution implying that intracellular trafficking of functional protein may occur under appropriate conditions [60]. Importantly, as in the case of $\mathrm{BCa}$, the Nav1.5 expression level correlated with unfavourable disease-free survival (Figure 2D) [42]. Also, high-level Nav1.5 expression was associated positively with estrogen receptor- $\beta$ expression [42], implying that VGSC/nNav1.5 expression in colon cancer may be under estrogenic control, as in BCa [61] and some neurones [62,63]. As already suggested for the EGF connection in NSCLC, this could form the basis of further combination therapy options for metastatic colon cancer.

In conclusion, VGSC protein expression in cancer tissues generally but not universally reflects the in vitro cellular studies. We should note, however, that publicly available databases, such as the Human Protein Atlas, or even the Cancer Proteome Atlas, have limited, even conflicting, information [50]. Such apparent discrepancies, in case of the latter, may be due to the quality of the available VGSC 'subtype-specific' antibodies. On the other hand, studies of cancers expressing nNav1.5 have given more consistent data thanks to the availability of the highly specific NESOpAb antibody.

\section{Tissue Electrolytes}

Currently, there is no report of VGSC activity recording from intact cancers in human patients. However, as already noted, it has been demonstrated that VGSC currents can be recorded from primary cultures of human cervical cancer and mesothelioma cells taken from biopsies [20,21]. Also, Nelson et al. (2015) showed that VGSC activity can be recorded in slices of BCa tumour taken from mouse xenografts [11]. Thus, it would appear that functional VGSC expression is maintained in cancer cells isolated from tumours and tissues. VGSC activity would implicitly lead to a rise in the concentration of intracellular $\mathrm{Na}^{+}$, and this has been measured in vitro [31,64]. Such a rise could be detectable in vivo as an increase in tissue $\mathrm{Na}^{+}$level [65]. Indeed, Ouwerkerk et al. (2007) showed by 'non-invasive' semi-quantitative ${ }^{23} \mathrm{Na}$-magnetic resonance imaging (MRI) that the $\mathrm{Na}^{+}$content of locally advanced $\mathrm{BC}$ a tissue was higher than poorly differentiated ductal carcinoma which, in turn, was higher than benign tissue (Figure $4 \mathrm{~A}-\mathrm{C}$ ) [66]. A comparable result was obtained using ${ }^{23} \mathrm{Na}-\mathrm{MRI}$ 
for $\mathrm{PCa}$, wherein tissue $\mathrm{Na}^{+}$levels correlated with Gleason grading [67]. This was also observed for ovarian cancer [68]. In a rat model of hepatocellular carcinoma, it was also concluded that tumours had increased levels of tissue $\mathrm{Na}^{+}$and intracellular $\mathrm{Na}^{+}$[69]. Importantly, as well as being an early indicator of metastatic disease, the $\mathrm{Na}^{+}$content of tumours (as measured by ${ }^{23} \mathrm{Na}-\mathrm{MRI}$ ) has also been suggested as being useful in monitoring the effectiveness of therapy [70-74]. Another measurement technique, complementary to ${ }^{23} \mathrm{Na}$-MRI, is magnetic resonance spectroscopic imaging (MRSI), which uses radio frequency transmission reception to map relative concentrations of metabolic markers of disease [75]. Thus, using MRSI, Barrett et al. showed that PCa tissue $\mathrm{Na}^{+}$levels were significantly higher than those in adjacent normal tissue (Figure 4D,E) [76].

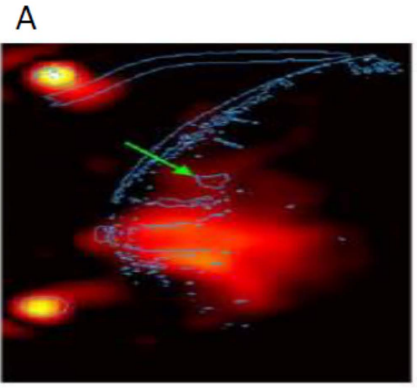

Benign lesion
B

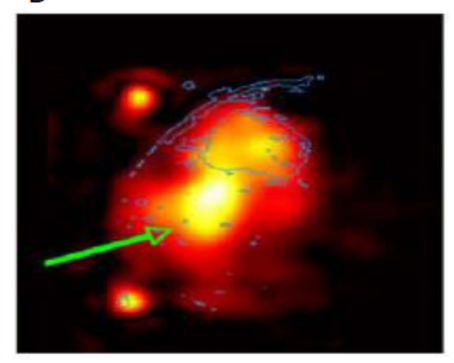

Poorly differentiated, ductal carcinoma
C

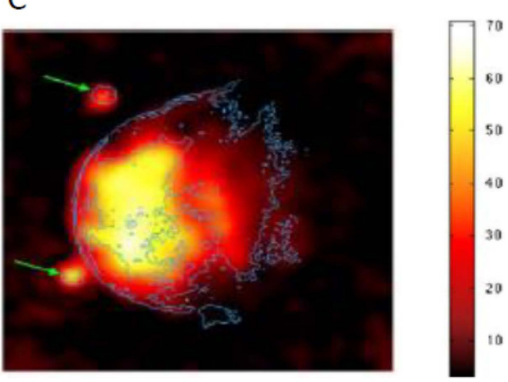

Locally advanced $\mathrm{BCa}$

D
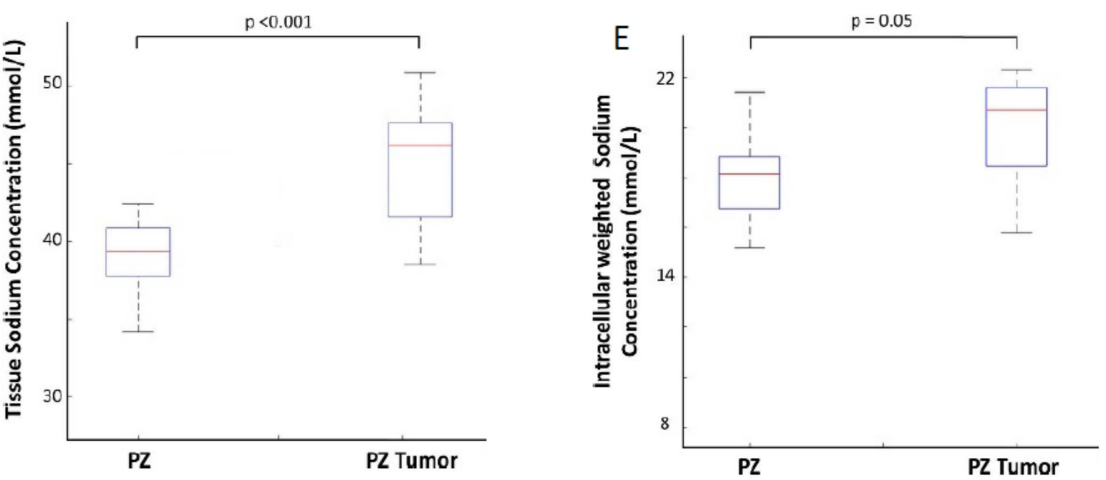

Figure 4. Clinical measurement of tissue sodium levels in breast cancer (BCa) and prostate cancer (PCa) with magnetic resonance imagining (MRI). (A-C) ${ }^{23} \mathrm{Na}-\mathrm{MRI}$ 's from three different BCa patients. (A) A benign lesion (proliferative fibrocystosis), indicated by the arrow, aligned from gadolinium-enhanced image. (B) Infiltrating poorly differentiated ductal carcinoma (outlined in blue). Below (indicated by the green arrow) is a region with edema. (C) A large locally advanced BCa (outline in blue). The arrows indicate positioning landmarks. The intensity scale on the far right indicates approximate sodium concentrations (relative). Modified from [66]. (D,E) Magnetic resonance spectroscopic imaging (MRSI) of prostate. (D) Box plots of the tissue sodium concentration in normal and PCa tissue in peripheral zone (PZ) showing significantly increased sodium level in the latter. (E) Same as (D), but showing intracellular-weighted sodium concentration. Modified from [76].

Electrolyte analyses have also been carried out on human body fluids. Thus, Sisman et al. (2009) showed that extracellular fluid from breast cysts associated with higher risk of developing cancer had lower $\mathrm{Na}^{+}$, higher $\mathrm{K}^{+}$, and, hence, a lower $\mathrm{Na}^{+}: \mathrm{K}^{+}$concentration ratio than those with lower risk [77]. These changes would appear to mirror those seen in tissue. It is well known that cancer is associated clinically with various changes in body electrolyte levels [78]. One of these is "hyponatraemia", where serum sodium level is reduced in parallel with a poor prognosis [79]. However, it is not currently known if this involves tumour VGSC activity. Such assessments of tumour-associated changes in body 
electrolyte levels ("fluid cytology") would offer the advantage of being 'low-tech', hence cheaper and potentially more readily available to pathologists.

Importantly, the $\mathrm{Na}^{+}$influx expected from VGSC-driven (millisecond long) action potential activity would raise intracellular $\mathrm{Na}^{+}$only in the picomolar range [80]. Thus, this is an unlikely source of the increased $\mathrm{Na}^{+}$levels of cancer tissues and unlikely to make an impact on $\mathrm{Na}^{+}$-dependent metastatic cell behaviours. A more likely mechanism is the persistent current component of the VGSC. This is enhanced under hypoxic conditions that develop naturally in growing tumours. $\mathrm{I}_{\mathrm{NaP}}$ can outlast the transient current by hundreds of milliseconds-seconds and could well lead to millimolar changes in the intracellular/tissue level of $\mathrm{Na}^{+}$, sufficient to significantly affect $\mathrm{Na}^{+}$-dependent cellular mechanisms including NHE1 activity. Indeed, inhibiting $\mathrm{I}_{\mathrm{NaP}}$ (e.g., by ranolazine) has been shown to produce anti-invasive effects on colon cancer and BCa in vitro $[13,81]$. Also, as detailed in the next section, ranolazine has been shown to inhibit BCa and PCa metastasis in vivo [12,50]. Accordingly, $\mathrm{I}_{\mathrm{NaP}}$ inhibitors may serve clinically as anti-metastatic drugs [36].

\section{In Vivo Animal Tests}

Several preclinical animal studies have been carried out to evaluate the involvement of VGSCs in tumour progression in vivo. In the first such study, a subcutaneous allograft model of PCa using metastatic Mat-LyLu cells injected subcutaneously in the Copenhagen rat was used [53]. TTX (200 nM; every 2 days) was injected directly into the primary tumour (i) to ensure access to the metastasising cells, (ii) to eliminate any possible side effect because TTX is a highly specific blocker of VGSCs, and (iii) to avoid systemic toxicity because the toxin is potentially lethal. This treatment regime significantly reduced the number of lung metastases at a level greater than $40 \%$. Presumably as a result of the reduction in the metastatic burden, there was also a significant increase in survival by some $20 \%$ [53]. Batcioglu et al. (2012) adopted the rat DMBA (7,12-dimethylbenz(a)anthracene) model of BCa with systemic application of RS100642 [82], an analogue of mexiletine, a blocker of TTX-R VGSCs, including Nav1.5 [83]. This study showed that a range of antioxidant responses (including superoxide dismutase, glutathione peroxidase, malondialdehyde) were suppressed significantly, presumably by reduction of the tumour burden. Importantly, also, as in the study of Yildirim et al. (2012) [53], survival was increased by some $26 \%$ [82]. These early data suggested that VGSC inhibition may have therapeutic value in vivo.

Subsequently, an orthotopic xenograft mouse model of BCa using metastatic MDA-MB-231 cells injected into the fourth inguinal mammary fat pad of female immunodeficient mice was used to show the involvement of Nav1.5 in tumour progression in vivo (Figure 5A-C) [11]. Using lentiviral shRNA, it was shown that knock-down of Nav1.5 slowed primary tumour growth, reduced MMP9 expression, increased apoptosis, and inhibited local invasion and metastasis to the liver, lungs, and spleen [11]. In addition, using ex vivo tumour tissue slice patch clamp recording, it was shown that functional $\mathrm{Na}^{+}$ currents carried by Nav1.5 were maintained in vivo, supporting the notion that VGSC expression is not an artefact of in vitro cell culture conditions [11]. 

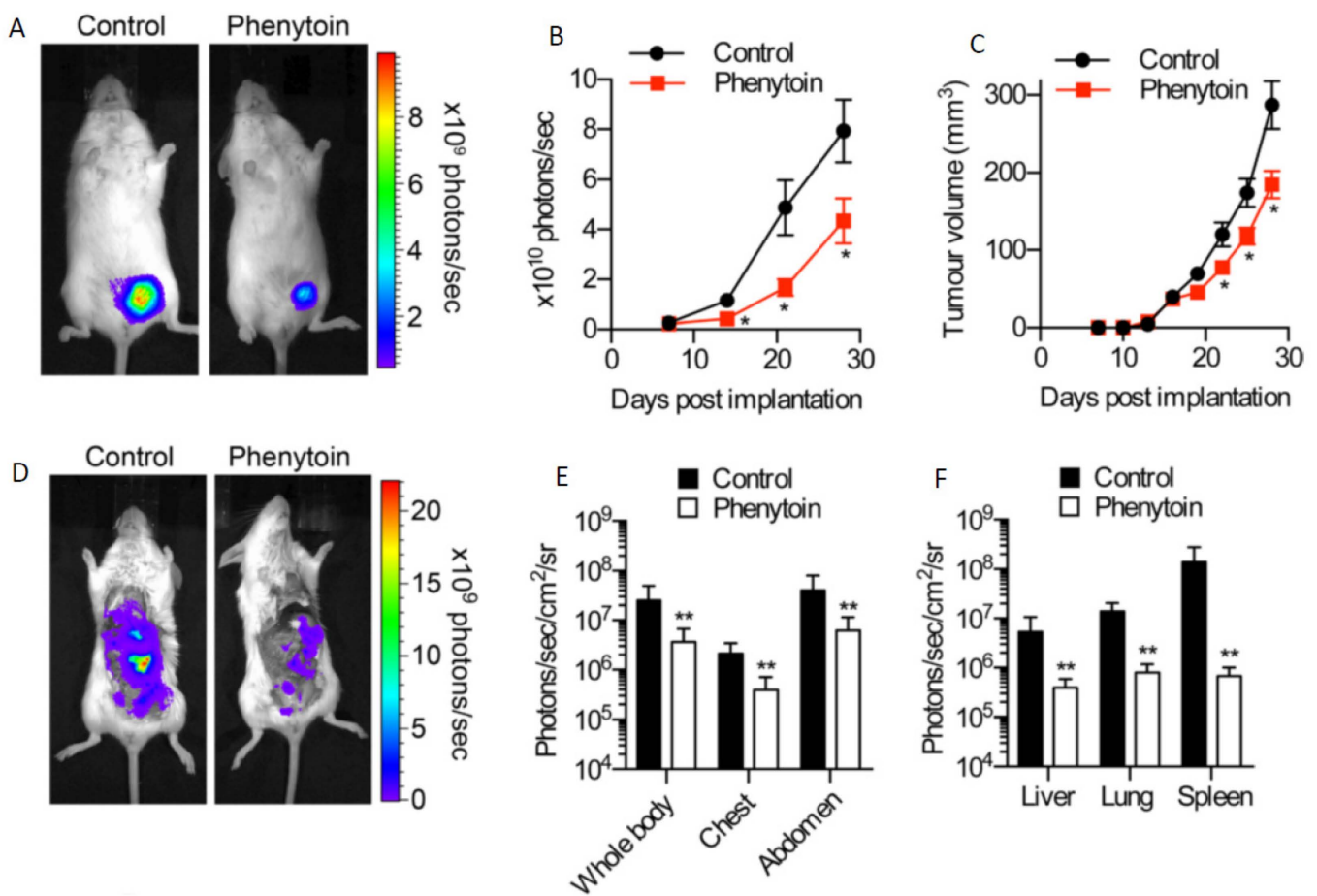

Figure 5. In vivo evidence showing suppression of breast cancer metastasis in a mouse ('orthotopic') model by blocking VGSC activity with phenytoin. (A) Bioluminescent images of control and phenytoin-treated mice, 4 weeks after implantation. (B) Bioluminescence measured from primary tumours on the indicated days post-implantation. Bioluminescence was quantified as indicated on the vertical axes. (C) Calculated volume derived from calliper measurement of primary tumours over the same period. (D) Bioluminescent images of metastases in control and phenytoin-treated mice. (E) Bioluminescence measured from the indicated anatomical sites. (F) Bioluminescence measured ex vivo from liver, lungs, and spleen. Data are means \pm standard error of the means (SEMs). Asterisks $\left({ }^{* \prime} \mathrm{s}\right)$ indicate statistically significant differences (cf. corresponding controls). Modified from [84].

Some work has also been done on VGSC beta subunits. Stable over-expression of $\beta 1$, which occurs endogenously at low levels in MDA-MB-231 cells [85] as well as in BCa and PCa biopsy tissues [86,87], significantly reduced apoptosis within the primary tumour and increased angiogenesis, tumour growth, and distant metastasis [87]. In contrast, over-expression of $\beta 2$ in PCa (LNCaP) cells reduced tumour growth when the cells were subcutaneously implanted into immunodeficient mice [88]. In human cancer (including CRCa and NSCLC) cell lines, expression of SCN3B (the gene encoding $\beta 3$ ) was found to be upregulated by DNA-damaging agents and by overexpression of p53 [89]. Importantly, in vivo (in p53(+/+) mice), SCN3B was also similarly upregulated following adriamycin treatment. It was concluded that $S C N 3 B$ was involved in a proapoptotic pathway and may serve as a tumour suppressor [89]. In similar fashion, in mice with $\beta 4$-silenced MDA-MB-231 cell xenografts, tumour growth, invasiveness, and metastasis were enhanced. These occurred independently of VGSC activity and suggested that $S C N 4 B$ (the gene encoding $\beta 4$ ) functions by itself as a tumour suppressor [90]. Consistent with these in vivo data, $\beta 4$ expression was low/absent in BCa and cervical cancer tissues $[90,91]$. In addition, in papillary thyroid cancer $S C N 4 B$ was downregulated at both RNA and protein levels in comparison with normal thyroid tissues, and sustained SCN4B expression was an independent indicator of favourable recurrence-free survival [92]. Together, these studies suggested that both Nav1.5 and $\beta 1$ can promote, whereas $\beta 2, \beta 3$ and $\beta 4$ may suppress cancer progression in vivo.

Following on from these observations, several studies have explored the potential value of pharmacologically inhibiting VGSCs in vivo using clinically-approved blockers [93]. Using the same orthotopic xenograft BCa model described above, it was shown that the Class $1 \mathrm{~b}$ antiarrhythmic and antiepileptic phenytoin (daily intraperitoneal injection $60 \mathrm{mg} / \mathrm{kg}$ ) significantly reduced proliferation, 
primary tumour growth, local invasion, and distant metastasis (Figure 5D-F) [84]. In an experimental metastasis model, in which MDA-MB-231 cells are injected intravenously to form lung metastases, it was shown (i) that silencing Nav1.5 completely suppressed metastasis and (ii) that the anti-anginal VGSC-I $\mathrm{I}_{\mathrm{NaP}}$ inhibitor ranolazine (intraperitoneal $50 \mathrm{mg} / \mathrm{kg} /$ day) significantly reduced lung colonisation (Figure 6A-E) [12]. In a peritoneal carcinomatosis model, direct administration of the VGSC-inhibiting local anaesthetic lidocaine $(100 \mathrm{mg} / \mathrm{kg}$ once weekly) following intraperitoneal injection of MDA-MB-231 cells into female immunodeficient mice, resulted in a significant reduction in tumour burden and prolongation of survival [94]. In the 4T1 mouse orthotopic allograft model of $\mathrm{BCa}$, lidocaine (intravenous $1.5 \mathrm{mg} / \mathrm{kg}$ bolus followed by $25 \mathrm{~min}$ infusion $2 \mathrm{mg} / \mathrm{kg} / \mathrm{h}$ ) administered during tumour resection significantly reduced pulmonary metastasis, but only when combined with sevoflurane and not with ketamine, suggesting that perioperative administration of VGSC inhibitors may have therapeutic value that is dependent on the anaesthetic combinations used [95]. In the same model, also under sevoflurane anaesthesia, both perioperative propofol $(5 \mathrm{mg} / \mathrm{kg})$ and lidocaine were shown to lead to a reduction in pulmonary metastases [96]. Lidocaine also enhanced the anti-metastatic effect of cisplatin [97]. In a similar study on hepatocellular carcinoma, lidocaine both suppressed tumour development of human HepG2 cell xenografts in BALB/c nude mice and enhanced sensitivity to cisplatin [98]. Procaine was also found to reduce tumour volume in BALB/c nude mice HLE hepatoma cell xenografts in vivo [99]. The functional role of Nav1.7 in gastric cancer growth was confirmed in a xenograft experiment in vivo [23]. Finally, in the Copenhagen rat model of prostate cancer, ranolazine (2.5-5 $\mu \mathrm{M}$; oral gavage) decreased lung metastatic burden following subcutaneous implantation of Mat-LyLu cells, without affecting primary tumour growth [50].
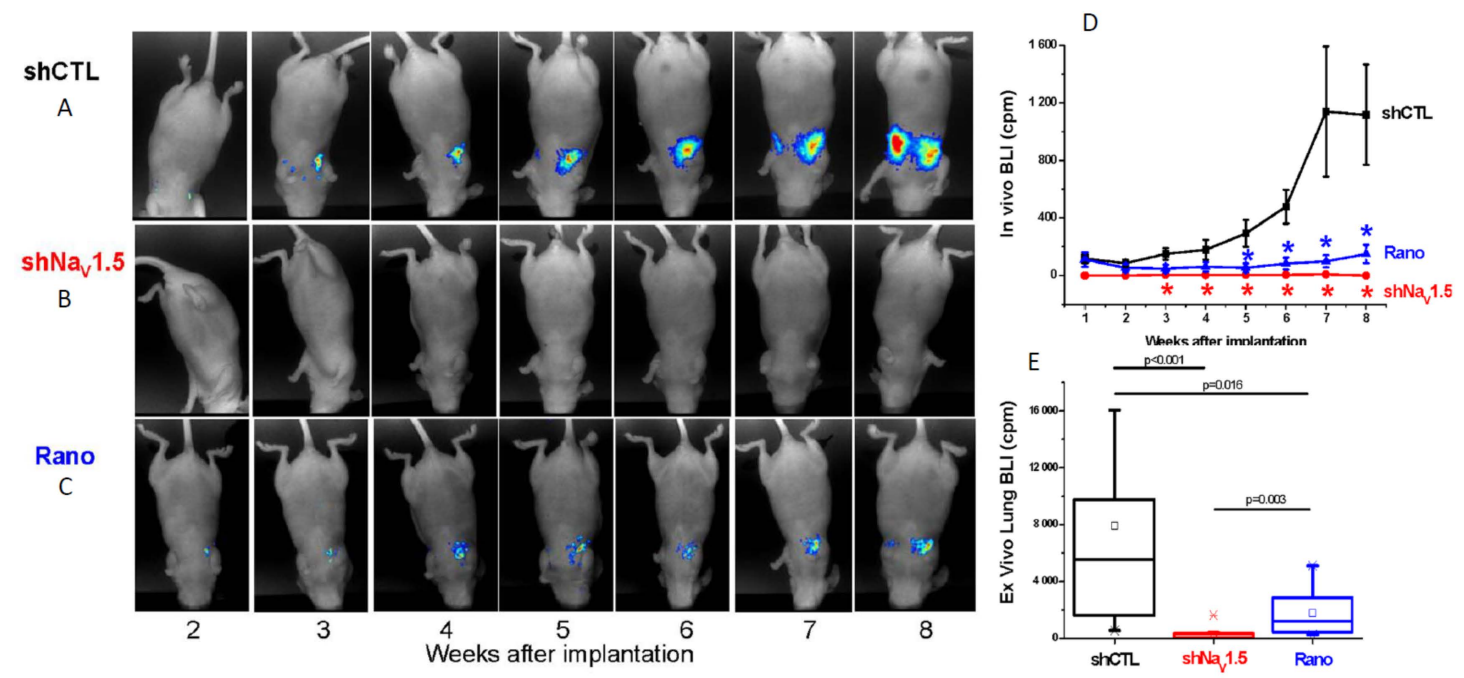

Figure 6. In vivo evidence showing suppression of breast cancer (BCa) metastasis in a mouse ('tail vein') model by silencing of Nav1.5 and ranolazine. (A) Bioluminescent imaging (BLI) of living nude mice inoculated with human BCa MDA-MB-231 cells and followed over 8 weeks ("shCTL"). Representative images are shown. (B) Cells with Nav1.5 'silenced' with short-hairpin (sh) Nav1.5 ("shNav1.5"). (C) As for the control, but mice were treated (5 days/week) with $50 \mathrm{mg} / \mathrm{kg}$ ranolazine ("Rano"). (D) Data quantified from (A-C). Tumourigenesis in intact mice was quantified as BLI value expressed in "counts per minute" (cpm). Asterisks (*'s) indicate statistically significant differences (cf. shCTL). (E) Quantification and statistical analyses of BLI values measured ex vivo from lungs (excised after 8 weeks of experimentation). Modified from [12].

Taken together, these various studies suggested that administration of VGSC-inhibiting drugs may help to slow cancer progression in vivo by suppressing metastasis, and in some models, primary tumour growth. Also, where it could be studied, such treatments prolonged survival. 


\section{Clinical Studies}

The combined in vitro and in vivo preclinical evidence suggest that repurposing VGSC-inhibiting medication to the oncology setting may have therapeutic value. Given that such drugs are in widespread clinical use for other indications, several observational studies have investigated potential associations with cancer outcomes [100-102]. For example, it has been shown that the risk of recurrence in patients with $\mathrm{BCa}$ or PCa who received general anaesthesia and perioperative lidocaine was reduced compared to those who did not receive lidocaine $[103,104]$. On the other hand, retrospective analysis of PCa incidence using the Taiwan Longitudinal Health Insurance Database 2005 found no association between VGSC blocker use and cancer risk [105]. Another retrospective cohort study using the QResearch database and seeking to investigate the relationship between prescription of VGSC-inhibiting antiepileptic medication and overall survival of breast, colorectal, and prostate cancer patients demonstrated, rather surprisingly, significantly shortened overall survival in cancer patients exposed to VGSC-inhibiting antiepileptic medications [106]. Although the reasons for this negative association are not clear, it is likely that increased mortality in the drug-exposed group may be the result of confounding by indication, thereby masking any potential beneficial effect in the population [107]. Other studies revealed the predicted inverse association between use of VGSC blocking drugs and survival. Retrospective analysis of cancer occurrence using the United States Food and Drug Administration Adverse Event Reporting System and an insurance claims database (containing 3 million cases) demonstrated significant inverse association between use of VGSC-inhibiting antiepileptic medications and diagnoses of colorectal cancer, lung cancer, gastric cancer, and haematological malignancies [108]. Similarly, a case-control study using the General Practice Research Database showed significantly reduced prescription of VGSC-inhibiting tricyclic antidepressants in colorectal cancer (and glioma) patients, suggesting that these medications may also be effective for reducing recurrence of certain cancers [109].

VGSC inhibitors may also have an added benefit in combination with existing treatments. An observational study of records from 253 patients with BCa brain metastases who had undergone whole brain radiotherapy (WBRT) showed that the overall survival of those receiving antiepileptic drugs was significantly longer than for patients not receiving such medication, although this association may be due to reduced mortality from better control of seizures caused by WBRT [110]. Administration of anti-epileptic drugs improved overall survival in Her2 ${ }^{+}$BCa patients and those undergoing surgery [110]. Suppressing the activation of VGSC- $\mathrm{I}_{\mathrm{NaP}}$ by certain chemotherapeutic drugs, including anthracyclines, could reduce the cardiotoxicity associated with standard-of-care therapies [111]. Such a possibility is the focus of a proof-of-concept clinical study of the efficacy and safety of ranolazine in cancer patients [112]. It has also been shown that epilepsy-related mutations in SCN1A (encoding for Nav1.1) are associated with significantly shortened recurrence-free survival in CRCa patients treated with 5-fluoruracil adjuvant chemotherapy [113]. These studies add further evidence supporting the notion that VGSC expression may be useful predictive biomarkers and therapeutic targets, including potentially in combination with other therapies.

On balance, several retrospective observational studies have suggested a positive association between exposure to VGSC-inhibiting medications and cancer outcomes, although the data are partially conflicting. Such studies suffer by design from multiple confounding variables limiting their value. Therefore, there is a compelling case to justify the implementation of appropriately controlled prospective clinical trials. Notably, several trials of VGSC-inhibiting antiepileptic and local anaesthetic drugs are already registered/recruiting. Importantly, within the context the VGSC hypothesis, only one so far is specifically designed to assess the in vivo ability of local anaesthetic agents (e.g., lignocaine) for operable BCa in order to decrease the dissemination of cancer cells during surgery and improve disease-free survival (ClinicalTrials.gov identifier: NCT01916317; estimated completion date: December 2023). 


\section{Conclusions and Future Perspective}

In overall conclusion, there is increasing substantial evidence for VGSC expression in tumours in vivo, including in human tissues, at a hierarchy of levels from cellular mRNA to clinical studies. This VGSC expression is functional, whereby channel activity promotes metastatic cell behaviours in vitro and metastasis in vivo. Such expression offers several advantages as an anti-cancer target with significant clinical advantages and possibilities of application, as summarised in Table 2. Diagnostics: The early expression of the VGSC in the cancer/metastatic process would make it an ideal biomarker in decision-making, especially with regards to possible radical surgery. Furthermore, the possible cancer specificity of VGSC subtypes such as nNav1.5 (and an antibody for it) can facilitate this process, as well as help identify those patients who might benefit from VGSC-based therapies. Therapeutics: We propose that it would be timely to test VGSC blockers as anti-metastatic drugs in carefully planned clinical trials. An obvious first step would be to test existing clinical drugs, such as anti-epileptics (e.g., phenytoin) or anti-angina drugs (e.g., ranolazine), on the basis of 'repurposing' [36,114,115].

Table 2. Essential properties of the VGSC that would make it a clinically viable anti-metastatic target.

\begin{tabular}{|c|c|c|}
\hline VGSC Property & Clinical Consequence(s) & Reference(s) \\
\hline $\begin{array}{c}\text { Expression is early and upstream of the genes } \\
\text { driving invasiveness }\end{array}$ & Potential functional 'early' marker, ideal for diagnostics & {$[14]$} \\
\hline $\begin{array}{l}\text { Upregulation maintained at protein and } \\
\text { functional (signalling) levels }\end{array}$ & $\begin{array}{c}\text { Diagnostics can be extended to conventional } \\
\text { immunohistochemistry and even clinical imaging of } \\
\text { tissue sodium possibly resulting from channel activity } \\
\left.\text { (e.g., }{ }^{23} \mathrm{Na}-\mathrm{MRI}\right) \text {; expression can be used to determine } \\
\text { treatment strategy and efficacy }\end{array}$ & {$[9,16,57,65,66]$} \\
\hline $\begin{array}{l}\text { Gene/protein expressed in neonatal splice } \\
\text { form in several carcinomas; targetable } \\
\text { by antibody }\end{array}$ & $\begin{array}{c}\text { Diagnostics can be made even more specific; antibody } \\
\text { can also be used as a drug (i) to block channel } \\
\text { activity/metastasis and/or (ii) kill tumour cells (in } \\
\text { antibody-drug conjugate mode) }\end{array}$ & {$[9,10,56]$} \\
\hline $\begin{array}{l}\text { Promotes a range of cellular behaviours } \\
\text { integral to the metastatic cascade in vitro, as } \\
\text { well as metastasis per se in vivo }\end{array}$ & $\begin{array}{l}\text { Therapeutic potential-possible 'repurposing' of } \\
\text { existing VGSC drugs, } \mathrm{I}_{\mathrm{NaP}} \text { blockers (as well as novel } \\
\text { antibody), possibly with minimal side effects }\end{array}$ & {$[11,12,36,114]$} \\
\hline $\begin{array}{l}\text { Functional expression under the control of } \\
\text { steroid hormones and growth factors }\end{array}$ & $\begin{array}{l}\text { Therapeutic potential extended to } \\
\text { 'combination' treatments }\end{array}$ & {$[19,61]$} \\
\hline
\end{tabular}

Funding: We are grateful to the Pro Cancer Research Fund (PCRF) for continued support (M.B.A.D. and S.P.F.). W.J.B. was supported by Cancer Research U.K. (A25922).

Conflicts of Interest: M.B.A.D. is involved in a spinout company (Celex Oncology Innovations Ltd.) focused on ion channels and cancer. The other authors declare that they have no conflict of interest.

\section{References}

1. Bray, F.; Ferlay, J.; Soerjomataram, I.; Siegel, R.L.; Torre, L.A.; Jemal, A. Global cancer statistics 2018: GLOBOCAN estimates of incidence and mortality worldwide for 36 cancers in 185 countries. CA A Cancer J. Clin. 2018, 68, 394-424. [CrossRef]

2. Ferlay, J.; Colombet, M.; Soerjomataram, I.; Dyba, T.; Randi, G.; Bettio, M.; Gavin, A.; Visser, O.; Bray, F. Cancer incidence and mortality patterns in Europe: Estimates for 40 countries and 25 major cancers in 2018. Eur. J. Cancer 2018, 103, 356-387. [CrossRef] [PubMed]

3. Djamgoz, M.B.A.; Coombes, R.C.; Schwab, A. Ion transport and cancer: From initiation to metastasis. Philos. Trans. R. Soc. Lond. B Biol. Sci. 2014, 369, 20130092. [CrossRef] [PubMed] 
4. Lastraioli, E.; Iorio, J.; Arcangeli, A. Ion channel expression as promising cancer biomarker. Biochim. et Biophys. Acta 2015, 1848, 2685-2702. [CrossRef] [PubMed]

5. Prevarskaya, N.; Skryma, R.; Shuba, Y. Ion channels in cancer: Are cancer hallmarks oncochannelopathies? Physiol. Rev. 2018, 98, 559-621. [CrossRef] [PubMed]

6. Tuszynski, J.; Tilli, T.M.; Levin, M. Ion channel and neurotransmitter modulators as electroceutical approaches to the control of cancer. Curr. Pharm. Des. 2017, 23, 4827-4841. [CrossRef] [PubMed]

7. Grimes, J.A.; Fraser, S.P.; Stephens, G.J.; Downing, J.E.; Laniado, M.E.; Foster, C.S.; Abel, P.D.; Djamgoz, M.B.A. Differential expression of voltage-activated $\mathrm{Na}^{+}$currents in two prostatic tumour cell lines: Contribution to invasiveness in vitro. FEBS Lett. 1995, 369, 290-294. [CrossRef]

8. Laniado, M.E.; Lalani, E.-N.; Fraser, S.P.; Grimes, J.A.; Bhangal, G.; Djamgoz, M.B.A.; Abel, P.D. Expression and functional analysis of voltage-activated $\mathrm{Na}^{+}$channels in human prostate cancer cell lines and their contribution to invasion in vitro. Am. J. Pathol. 1997, 150, 1213-1221.

9. Fraser, S.P.; Diss, J.K.J.; Chioni, A.M.; Mycielska, M.; Pan, H.; Yamaci, R.F.; Pani, F.; Siwy, Z.; Krasowska, M.; Grzywna, Z.; et al. Voltage-gated sodium channel expression and potentiation of human breast cancer metastasis. Clin. Cancer Res. 2005, 11, 5381-5389. [CrossRef]

10. Brackenbury, W.J.; Chioni, A.M.; Diss, J.K.J.; Djamgoz, M.B.A. The neonatal splice variant of Nav1.5 potentiates in vitro invasive behaviour of MDA-MB-231 human breast cancer cells. Breast Cancer Res. Treat. 2007, 101, 149-160. [CrossRef]

11. Nelson, M.; Yang, M.; Millican-Slater, R.; Brackenbury, W.J. Nav1.5 regulates breast tumor growth and metastatic dissemination in vivo. Oncotarget 2015, 6, 32914-32929. [CrossRef] [PubMed]

12. Driffort, V.; Gillet, L.; Bon, E.; Marionneau-Lambot, S.; Oullier, T.; Joulin, V.; Collin, C.; Pagès, J.C.; Jourdan, M.L.; Chevalier, S.; et al. Ranolazine inhibits Nav1.5-mediated breast cancer cell invasiveness and lung colonization. Mol. Cancer 2014, 13, 264. [CrossRef] [PubMed]

13. Guzel, R.M.; Ogmen, K.; Ilieva, K.M.; Fraser, S.P.; Djamgoz, M.B.A. Colorectal cancer invasiveness in vitro: Predominant contribution of neonatal Nav1.5 under normoxia and hypoxia. J. Cell. Physiol. 2019, 234, 6582-6593. [CrossRef] [PubMed]

14. House, C.D.; Vaske, C.J.; Schwartz, A.; Obias, V.; Frank, B.; Luu, T.; Sarvazyan, N.; Irby, R.; Strausberg, R.L.; Hales, T.G.; et al. Voltage-gated $\mathrm{Na}^{+}$channel SCN5A is a key regulator of a gene transcriptional network that controls colon cancer invasion. Cancer Res. 2010, 70, 6957-6967. [CrossRef] [PubMed]

15. Baptista-Hon, D.T.; Robertson, F.M.; Robertson, G.B.; Owen, S.J.; Rogers, G.W.; Lydon, E.L.; Lee, N.H.; Hales, T.G. Potent inhibition by ropivacaine of metastatic colon cancer SW620 cell invasion and Nav1.5 channel function. Br. J. Anaesth. 2014, 113, i39-i48. [CrossRef] [PubMed]

16. Diss, J.K.J.; Stewart, D.; Pani, F.; Foster, C.S.; Walker, M.M.; Patel, A.; Djamgoz, M.B.A. A potential novel marker for human prostate cancer: Voltage-gated sodium channel expression in vivo. Prostate Cancer Prostatic Dis. 2005, 8, 266-273. [CrossRef] [PubMed]

17. Nakajima, T.; Kubota, N.; Tsutsumi, T.; Oguri, A.; Imuta, H.; Jo, T.; Oonuma, H.; Soma, M.; Meguro, K.; Takano, H.; et al. Eicosapentaenoic acid inhibits voltage-gated sodium channels and invasiveness in prostate cancer cells. Br. J. Pharmacol. 2009, 156, 420-431. [CrossRef]

18. Chen, B.; Zhang, C.; Wang, Z.; Chen, Y.; Xie, H.; Li, S.; Liu, X.; Liu, Z.; Chen, P. Mechanistic insights into Nav1.7-dependent regulation of rat prostate cancer cell invasiveness revealed by toxin probes and proteomic analysis. FEBS J. 2019, 286, 2549-2561. [CrossRef]

19. Campbell, T.M.; Main, M.J.; Fitzgerald, E.M. Functional expression of the voltage-gated $\mathrm{Na}^{+}$-channel Nav1.7 is necessary for EGF-mediated invasion in human non-small cell lung cancer cells. J. Cell Sci. 2013, 126, 4939-4949. [CrossRef]

20. Fulgenzi, G.; Graciotti, L.; Faronato, M.; Soldovieri, M.V.; Miceli, F.; Amoroso, S.; Annunziato, L.; Procopio, A.; Taglialatela, M. Human neoplastic mesothelial cells express voltage-gated sodium channels involved in cell motility. Int. J. Biochem. Cell Biol. 2006, 38, 1146-1159. [CrossRef]

21. Diaz, D.; Delgadillo, D.M.; Hernandez-Gallegos, E.; Ramirez-Dominguez, M.E.; Hinojosa, L.M.; Ortiz, C.S.; Berumen, J.; Camacho, J.; Gomora, J.C. Functional expression of voltage-gated sodium channels in primary cultures of human cervical cancer. J. Cell. Physiol. 2007, 210, 469-478. [CrossRef] [PubMed]

22. Hernandez-Plata, E.; Ortiz, C.S.; Marquina-Castillo, B.; Medina-Martinez, I.; Alfaro, A.; Berumen, J.; Rivera, M.; Gomora, J.C. Overexpression of Nav1.6 channels is associated with the invasion capacity of human cervical cancer. Int. J. Cancer 2012, 130, 2013-2023. [CrossRef] [PubMed] 
23. Xia, J.; Huang, N.; Huang, H.; Sun, L.; Dong, S.; Su, J.; Zhang, J.; Wang, L.; Lin, L.; Shi, M.; et al. Voltage-gated sodium channel Nav 1.7 promotes gastric cancer progression through MACC1-mediated upregulation of NHE1. Int. J. Cancer 2016, 139, 2553-2569. [CrossRef]

24. Gao, R.; Shen, Y.; Cai, J.; Lei, M.; Wang, Z. Expression of voltage-gated sodium channel alpha subunit in human ovarian cancer. Oncol. Rep. 2010, 23, 1293-1299. [PubMed]

25. Gao, R.; Cao, T.; Chen, H.; Cai, J.; Lei, M.; Wang, Z. Nav1.5-E3 antibody inhibits cancer progression. Transl. Cancer Res. 2019, 8, 44-50. [CrossRef]

26. Xie, A.; Gallant, B.; Guo, H.; Gonzalez, A.; Clark, M.; Madigan, A.; Feng, F.; Chen, H.D.; Cui, Y.; Dudley, S.C., Jr.; et al. Functional cardiac $\mathrm{Na}^{+}$channels are expressed in human melanoma cells. Oncol. Lett. 2018, 16, 1689-1695. [CrossRef]

27. Zhang, J.; Mao, W.; Dai, Y.; Qian, C.; Dong, Y.; Chen, Z.; Meng, L.; Jiang, Z.; Huang, T.; Hu, J.; et al. Voltage-gated sodium channel Nav1.5 promotes proliferation, migration and invasion of oral squamous cell carcinoma. Acta Biochim. Biophys. Sin. 2019, 51, 562-570. [CrossRef]

28. Xing, D.; Wang, J.; Ou, S.; Wang, Y.; Qiu, B.; Ding, D.; Guo, F.; Gao, Q. Expression of neonatal Nav1.5 in human brain astrocytoma and its effect on proliferation, invasion and apoptosis of astrocytoma cells. Oncol. Rep. 2014, 31, 2692-2700. [CrossRef]

29. Ou, S.W.; Kameyama, A.; Hao, L.Y.; Horiuchi, M.; Minobe, E.; Wang, W.Y.; Makita, N.; Kameyama, M. Tetrodotoxin-resistant $\mathrm{Na}^{+}$channels in human neuroblastoma cells are encoded by new variants of Nav1.5/SCN5A. Eur. J. Neurosci. 2005, 22, 793-801. [CrossRef]

30. Liu, J.; Tan, H.; Yang, W.; Yao, S.; Hong, L. The voltage-gated sodium channel Nav1.7 associated with endometrial cancer. J. Cancer 2019, 10, 4954-4960. [CrossRef]

31. Roger, S.; Rollin, J.; Barascu, A.; Besson, P.; Raynal, P.I.; Iochmann, S.; Lei, M.; Bougnoux, P.; Gruel, Y.; Le Guennec, J.Y. Voltage-gated sodium channels potentiate the invasive capacities of human non-small-cell lung cancer cell lines. Int. J. Biochem. Cell Biol. 2007, 39, 774-786. [CrossRef] [PubMed]

32. Djamgoz, M.B.A. Biophysics of cancer: Cellular excitability ("CELEX") hypothesis of metastasis. J. Clin. Exper. Oncol. 2014, S1, 005. [CrossRef]

33. Djamgoz, M.B.A. Bioelectricity of cancer: Voltage-gated ion channels and direct-current electric fields. In The Physiology of Bioelectricity in Development, Tissue Regeneration, and Cancer; Pullar, C., Ed.; Taylor \& Francis: London, UK, 2011; pp. 269-294.

34. Cabello, M.; Ge, H.; Aracil, C.; Moschou, D.; Estrela, P.; Manuel Quero, J.; Pascu, S.I.; Rocha, P.R.F. Extracellular electrophysiology in the prostate cancer cell model PC-3. Sensors 2019, 19, 139. [CrossRef] [PubMed]

35. Simon, A.; Yang, M.; Marrison, J.L.; James, A.D.; O’Toole, P.J.; Kaye, P.M.; Whittington, M.A.; Chawla, S.; Brackenbury, W.J. Metastatic breast cancer cells induce altered microglial morphology and electrical excitability in vivo. BioRxiv 2019. [CrossRef]

36. Djamgoz, M.B.A.; Onkal, R. Persistent current blockers of voltage-gated sodium channels: A clinical opportunity for controlling metastatic disease. Recent Pat. Anticancer Drug Discov. 2013, 8, 66-84. [CrossRef]

37. Brisson, L.; Gillet, L.; Calaghan, S.; Besson, P.; Le Guennec, J.Y.; Roger, S.; Gore, J. Nav1.5 enhances breast cancer cell invasiveness by increasing NHE1-dependent $\mathrm{H}^{+}$efflux in caveolae. Oncogene 2011, 30, $2070-2076$. [CrossRef]

38. Brisson, L.; Driffort, V.; Benoist, L.; Poet, M.; Counillon, L.; Antelmi, E.; Rubino, R.; Besson, P.; Labbal, F.; Chevalier, S.; et al. Nav1.5 $\mathrm{Na}^{+}$channels allosterically regulate the NHE-1 exchanger and promote the activity of breast cancer cell invadopodia. J. Cell Sci. 2013, 126, 4835-4842. [CrossRef]

39. Leanza, L.; Managò, A.; Zoratti, M.; Gulbins, E.; Szabo, I. Pharmacological targeting of ion channels for cancer therapy: In vivo evidences. Biochim. Biophys. Acta 2016, 1863, 1385-1397. [CrossRef]

40. Shan, B.; Dong, M.; Tang, H.; Wang, N.; Zhang, J.; Yan, C.; Jiao, X.; Zhang, H.; Wang, C. Voltage-gated sodium channels were differentially expressed in human normal prostate, benign prostatic hyperplasia and prostate cancer cells. Oncol. Lett. 2014, 8, 345-350. [CrossRef]

41. Yang, M.; Kozminski, D.J.; Wold, L.A.; Modak, R.; Calhoun, J.D.; Isom, L.L.; Brackenbury, W.J. Therapeutic potential for phenytoin: Targeting Nav1.5 sodium channels to reduce migration and invasion in metastatic breast cancer. Breast Cancer Res. Treat. 2012, 134, 603-615. [CrossRef]

42. Peng, J.; Ou, Q.; Wu, X.; Zhang, R.; Zhao, Q.; Jiang, W.; Lu, Z.; Wan, D.; Pan, Z.; Fang, Y. Expression of voltage-gated sodium channel Nav1.5 in non-metastatic colon cancer and its associations with estrogen receptor (ER)- $\beta$ expression and clinical outcomes. Chin. J. Cancer 2017, 36, 89. [CrossRef] [PubMed] 
43. Lopez-Charcas, O.; Espinosa, A.M.; Alfaro, A.; Herrera-Carrillo, Z.; Ramirez-Cordero, B.E.; Cortes-Reynosa, P.; Perez Salazar, E.; Berumen, J.; Gomora, J.C. The invasiveness of human cervical cancer associated to the function of Nav1.6 channels is mediated by MMP-2 activity. Sci. Rep. 2018, 8, 12995. [CrossRef] [PubMed]

44. Igci, Y.Z.; Bozgeyik, E.; Borazan, E.; Pala, E.; Suner, A.; Ulasli, M.; Gurses, S.A.; Yumrutas, O.; Balik, A.A.; Igci, M. Expression profiling of SCN8A and NDUFC2 genes in colorectal carcinoma. Exp. Oncol. 2015, 37, 77-80. [CrossRef]

45. Wu, W.K.; Li, G.R.; Wong, H.P.; Hui, M.K.; Tai, E.K.; Lam, E.K.; Shin, V.Y.; Ye, Y.N.; Li, P.; Yang, Y.H.; et al. Involvement of Kv1.1 and Nav1.5 in proliferation of gastric epithelial cells. J. Cell. Physiol. 2006, 207, 437-444. [CrossRef]

46. Pedersen, S.F.; Stock, C. Ion channels and transporters in cancer: Pathophysiology, regulation, and clinical potential. Cancer Res. 2013, 73, 1658-1661. [CrossRef]

47. Martin, K.C.; Zukin, R.S. RNA trafficking and local protein synthesis in dendrites: An overview. J. Neurosci. 2006, 26, 7131-7134. [CrossRef]

48. Pfeiffer, B.E.; Huber, K.M. Current advances in local protein synthesis and synaptic plasticity. J. Neurosci. 2006, 26, 7147-7150. [CrossRef]

49. Schedel, J.; Distler, O.; Woenckhaus, M.; Gay, R.E.; Simmen, B.; Michel, B.A.; Müller-Ladner, U.; Gay, S. Discrepancy between mRNA and protein expression of tumour suppressor maspin in synovial tissue may contribute to synovial hyperplasia in rheumatoid arthritis. Ann. Rheum. Dis. 2004, 63, 1205-1211. [CrossRef]

50. Bugan, I.; Kucuk, S.; Karagoz, Z.; Fraser, S.P.; Kaya, H.; Dodson, A.; Foster, C.S.; Altun, S.; Djamgoz, M.B.A. Anti-metastatic effect of ranolazine in an in vivo rat model of prostate cancer, and expression of voltage-gated sodium channel protein in human prostate. Prostate Cancer Prostatic Dis. 2019. [CrossRef]

51. Epstein, J.I.; Egevad, L.; Amin, M.B.; Delahunt, B.; Srigley, J.R.; Humphrey, P.A. Grading Committee. The 2014 International Society of Urological Pathology (ISUP) consensus Conference on Gleason grading of prostatic carcinoma: Definition of grading patterns and proposal for a new grading system. Am. J. Surg. Pathol. 2016, 40, 244-252. [CrossRef]

52. Suy, S.; Hansen, T.P.; Auto, H.D.; Kallakury, B.V.; Dailey, V.; Danner, M.; Macarthur, L.; Zhang, Y.; Miessau, M.J.; Collins, S.P.; et al. Expression of voltage-gated sodium channel Nav1.8 in human prostate cancer is associated with high histological grade. J. Clin. Exp. Oncol. 2012, 1. [CrossRef] [PubMed]

53. Yildirim, S.; Altun, S.; Gumushan, H.; Patel, A.; Djamgoz, M.B.A. Voltage-gated sodium channel activity promotes prostate cancer metastasis in vivo. Cancer Lett. 2012, 323, 58-61. [CrossRef] [PubMed]

54. Onganer, P.U.; Seckl, M.J.; Djamgoz, M.B.A. Neuronal characteristics of small-cell lung cancer. Br. J. Cancer 2005, 93, 1197-1201. [CrossRef] [PubMed]

55. Onkal, R.; Mattis, J.H.; Fraser, S.P.; Diss, J.K.J.; Shao, D.; Okuse, K.; Djamgoz, M.B.A. Alternative splicing of Nav1.5: An electrophysiological comparison of 'neonatal' and 'adult' isoforms, and critical involvement of a lysine residue. J. Cell. Physiol. 2008, 216, 716-726. [CrossRef]

56. Chioni, A.M.; Fraser, S.P.; Pani, F.; Foran, P.; Wilkin, G.P.; Diss, J.K.J.; Djamgoz, M.B.A. A novel polyclonal antibody specific for the Nav1.5 voltage-gated $\mathrm{Na}^{+}$channel 'neonatal' splice form. J. Neurosci. Methods 2005, 147, 88-98. [CrossRef]

57. Yamaci, R.F.; Fraser, S.P.; Battaloglu, E.; Kaya, H.; Erguler, K.; Foster, C.S.; Djamgoz, M.B.A. Neonatal Nav1.5 protein expression in normal adult human tissues and breast cancer. Pathol. Res. Prac. 2017, 213, 900-907. [CrossRef]

58. Guzel, R.M. Studies of Ionic Mechanisms Associated with Human Cancers. Ph.D. Thesis, Imperial College, London, UK, 2012.

59. Barshack, I.; Levite, M.; Lang, A.; Fudim, E.; Picard, O.; Ben Horin, S.; Chowers, Y. Functional voltage-gated sodium channels are expressed in human intestinal epithelial cells. Digestion 2008, 77, 108-117. [CrossRef]

60. Chioni, A.M.; Shao, D.; Grose, R.; Djamgoz, M.B.A. Protein kinase A and regulation of neonatal Nav1.5 expression in human breast cancer cells: Activity-dependent positive feedback and cellular migration. Int. J. Biochem. Cell Bio. 2010, 42, 346-358. [CrossRef]

61. Fraser, S.P.; Özerlat-Gunduz, I.; Brackenbury, W.J.; Fitzgerald, E.M.; Campbell, T.; Coombes, R.C.; Djamgoz, M.B.A. Regulation of voltage-gated sodium channel expression in cancer: Hormones, growth factors and auto-regulation. Philos. Trans. R. Soc. Lond. B. Biol. Sci. 2014, 369, 20130105. [CrossRef]

62. Zhang, C.; Bosch, M.A.; Qiu, J.; Rønnekleiv, O.K.; Kelly, M.J. 17ß-Estradiol increases persistent $\mathrm{Na}^{+}$current and excitability of AVPV/PeN Kiss1 neurons in female mice. Mol. Endocrinol. 2015, 29, 518-527. [CrossRef] 
63. Bi, R.Y.; Meng, Z.; Zhang, P.; Wang, X.D.; Ding, Y.; Gan, Y.H. Estradiol upregulates voltage-gated sodium channel 1.7 in trigeminal ganglion contributing to hyperalgesia of inflamed TMJ. PLoS ONE 2017, 12, e0178589. [CrossRef] [PubMed]

64. Li, L.; Li, P.; Fang, J.; Li, Q.; Xiao, H.; Zhou, H.; Tang, B. Simultaneous quantitation of $\mathrm{Na}^{+}$and $\mathrm{K}^{+}$in single normal and cancer cells using a new near-infrared fluorescent probe. Anal. Chem. 2015, 87, 6057-6063. [CrossRef] [PubMed]

65. Leslie, T.K.; James, A.D.; Zaccagna, F.; Grist, J.T.; Deen, S.; Kennerley, A.; Riemer, F.; Kaggie, J.D.; Gallagher, F.A.; Gilbert, F.J.; et al. Sodium homeostasis in the tumour microenvironment. Biochim. Biophys. Acta Rev. Cancer 2019. [CrossRef] [PubMed]

66. Ouwerkerk, R.; Jacobs, M.A.; Macura, K.J.; Wolff, A.C.; Stearns, V.; Mezban, S.D.; Khouri, N.F.; Bluemke, D.A.; Bottomley, P.A. Elevated tissue sodium concentration in malignant breast lesions detected with non-invasive ${ }^{23}$ Na MRI. Breast Cancer Res. Treat. 2007, 106, 151-160. [CrossRef]

67. Broeke, N.C.; Peterson, J.; Lee, J.; Martin, P.R.; Farag, A.; Gomez, J.A.; Moussa, M.; Gaed, M.; Chin, J.; Pautler, S.E.; et al. Characterization of clinical human prostate cancer lesions using 3.0-T sodium MRI registered to Gleason-graded whole-mount histopathology. J. Mag. Res. Imaging 2019, 49, 1409-1419. [CrossRef]

68. Deen, S.S.; Riemer, F.; McLean, M.A.; Gill, A.B.; Kaggie, J.D.; Grist, J.T.; Crawford, R.; Latimer, J.; Baldwin, P.; Earl, H.M.; et al. Sodium MRI with 3D-cones as a measure of tumour cellularity in high grade serous ovarian cancer. Eur. J. Radiol. Open 2019, 6, 156-162. [CrossRef]

69. Babsky, A.M.; Ju, S.; Bennett, S.; George, B.; McLennan, G.; Bansal, N. Effect of implantation site and growth of hepatocellular carcinoma on apparent diffusion coefficient of water and sodium MRI. NMR Biomed. 2012, 25, 312-321. [CrossRef]

70. Babsky, A.M.; Hekmatyar, S.K.; Zhang, H.; Solomon, J.L.; Bansal, N. Application of ${ }^{23}$ Na MRI to monitor chemotherapeutic response in RIF-1 tumors. Neoplasia 2005, 7, 658-666. [CrossRef]

71. Schepkin, V.D.; Chenevert, T.L.; Kuszpit, K.; Lee, K.C.; Meyer, C.R.; Johnson, T.D.; Rehemtulla, A.; Ross, B.D. Sodium and proton diffusion MRI as biomarkers for early therapeutic response in subcutaneous tumors. Magn. Reson. Imaging 2006, 24, 273-278. [CrossRef]

72. Schepkin, V.D.; Lee, K.C.; Kuszpit, K.; Muthuswami, M.; Johnson, T.D.; Chenevert, T.L.; Rehemtulla, A.; Ross, B.D. Proton and sodium MRI assessment of emerging tumor chemotherapeutic resistance. NMR Biomed. 2006, 19, 1035-1042. [CrossRef]

73. Kline, R.P.; Wu, E.X.; Petrylak, D.P.; Szabolcs, M.; Alderson, P.O.; Weisfeldt, M.L.; Cannon, P.; Katz, J. Rapid in vivo monitoring of chemotherapeutic response using weighted sodium magnetic resonance imaging. Clin. Cancer Res. 2000, 6, 2146-2156. [PubMed]

74. Jacobs, M.A.; Ouwerkerk, R.; Wolff, A.C.; Gabrielson, E.; Warzecha, H.; Jeter, S.; Bluemke, D.A.; Wahl, R.; Stearns, V. Monitoring of neoadjuvant chemotherapy using multiparametric, ${ }^{23} \mathrm{Na}$ sodium MR, and multimodality (PET/CT/ MRI) imaging in locally advanced breast cancer. Breast Cancer Res. Treat. 2011, 128, 119-126. [CrossRef] [PubMed]

75. Near, J.; Romagnoli, C.; Bartha, R. Reduced power magnetic resonance spectroscopic imaging of the prostate at 4.0 Tesla. Magn. Reson. Med. 2009, 61, 273-281. [CrossRef] [PubMed]

76. Barrett, T.; Riemer, F.; McLean, M.A.; Kaggie,J.; Robb, F.; Tropp,J.S.; Warren, A.; Bratt, O.; Shah, N.; Gnanapragasam, V.J.; et al. Quantification of total and intracellular sodium concentration in primary prostate cancer and adjacent normal prostate tissue with magnetic resonance imaging. Invest. Radiol. 2018, 53, 450-456. [CrossRef] [PubMed]

77. Sişman, A.R.; Sis, B.; Canda, T.; Onvural, B. Electrolytes and trace elements in human breast cyst fluid. Biol. Trace Element Res. 2009, 128, 18-30. [CrossRef] [PubMed]

78. Rosner, M.H.; Dalkin, A.C. Electrolyte disorders associated with cancer. Adv. Chronic Kidney Dis. 2014, $21,7-17$. [CrossRef] [PubMed]

79. Berardi, R.; Rinaldi, S.; Caramanti, M.; Grohè, C.; Santoni, M.; Morgese, F.; Torniai, M.; Savini, A.; Fiordoliva, I.; Cascinu, S. Hyponatremia in cancer patients: Time for a new approach. Crit. Rev. Oncol. Hematol. 2016, 102, 15-25. [CrossRef]

80. Carter, B.C.; Bean, B.P. Sodium entry during action potentials of mammalian central neurons: Incomplete inactivation and reduced metabolic efficiency in fast-spiking neurons. Neuron 2009, 64, 898-909. [CrossRef] 
81. Lee, A.; Fraser, S.P.; Djamgoz, M.B.A. Propranolol inhibits neonatal Nav1.5 activity and invasiveness of MDA-MB-231 breast cancer cells: Effects of combination with ranolazine. J. Cell. Physiol. 2019. [Epub ahead of print]. [CrossRef]

82. Batcioglu, K.; Uyumlu, A.B.; Satilmis, B.; Yildirim, B.; Yucel, N.; Demirtas, H.; Onkal, R.; Guzel, R.M.; Djamgoz, M.B.A. Oxidative stress in the in vivo DMBA rat model of breast cancer: Suppression by a voltage-gated sodium channel inhibitor (RS100642). Basic Clin. Pharmacol. Toxicol. 2012, 111, $137-141$. [CrossRef]

83. Sheets, M.F.; Fozzard, H.A.; Lipkind, G.M.; Hanck, D.A. Sodium channel molecular conformations and antiarrhythmic drug affinity. Trends Cardiovasc. Med. 2010, 20, 16-21. [CrossRef] [PubMed]

84. Nelson, M.; Yang, M.; Dowle, A.A.; Thomas, J.R.; Brackenbury, W.J. The sodium channel-blocking antiepileptic drug phenytoin inhibits breast tumour growth and metastasis. Mol. Cancer 2015, 14, 13. [CrossRef]

85. Chioni, A.M.; Brackenbury, W.J.; Calhoun, J.D.; Isom, L.L.; Djamgoz, M.B.A. A novel adhesion molecule in human breast cancer cells: Voltage-gated $\mathrm{Na}^{+}$channel beta1 subunit. Int. J. Biochem. Cell Biol. 2009, 41, 1216-1227. [CrossRef] [PubMed]

86. Diss, J.K.J.; Fraser, S.P.; Walker, M.M.; Patel, A.; Latchman, D.S.; Djamgoz, M.B.A. Beta-subunits of voltage-gated sodium channels in human prostate cancer: Quantitative in vitro and in vivo analyses of mRNA expression. Prostate Cancer and Prostatic Dis. 2008, 11, 325-333. [CrossRef] [PubMed]

87. Nelson, M.; Millican-Slater, R.; Forrest, L.C.; Brackenbury, W.J. The sodium channel beta1 subunit mediates outgrowth of neurite-like processes on breast cancer cells and promotes tumour growth and metastasis. Int. J. Cancer 2014, 135, 2338-2351. [CrossRef]

88. Jansson, K.H.; Lynch, J.E.; Lepori-Bui, N.; Czymmek, K.J.; Duncan, R.L.; Sikes, R.A. Overexpression of the VSSC-associated CAM, beta-2, enhances LNCaP cell metastasis associated behavior. Prostate 2012, 72, 1080-1092. [CrossRef]

89. Adachi, K.; Toyota, M.; Sasaki, Y.; Yamashita, T.; Ishida, S.; Ohe-Toyota, M.; Maruyama, R.; Hinoda, Y.; Saito, T.; Imai, K.; et al. Identification of SCN3B as a novel p53-inducible proapoptotic gene. Oncogene 2004, 23, 7791-7798. [CrossRef]

90. Bon, E.; Driffort, V.; Gradek, F.; Martinez-Caceres, C.; Anchelin, M.; Pelegrin, P.; Cayuela, M.L.; Marionneau-Lambot, S.; Oullier, T.; Guibon, R.; et al. SCN4B acts as a metastasis-suppressor gene preventing hyperactivation of cell migration in breast cancer. Nat. Commun. 2016, 7, 13648. [CrossRef]

91. Sanchez-Sandoval, A.L.; Gomora, J.C. Contribution of voltage-gated sodium channel $\beta$-subunits to cervical cancer cells metastatic behavior. Cancer Cell Int. 2019, 19, 35. [CrossRef]

92. Gong, Y.; Yang, J.; Wu, W.; Liu, F.; Su, A.; Li, Z.; Zhu, J.; Wei, T. Preserved SCN4B expression is an independent indicator of favorable recurrence-free survival in classical papillary thyroid cancer. PLoS One 2018, 13, e0197007. [CrossRef]

93. Martin, F.; Ufodiama, C.; Watt, I.; Bland, M.; Brackenbury, W.J. Therapeutic value of voltage-gated sodium channel inhibitors in breast, colorectal and prostate cancer: A systematic review. Front. Pharmacol. 2015, 6, 273. [CrossRef] [PubMed]

94. Chamaraux-Tran, T.N.; Mathelin, C.; Aprahamian, M.; Joshi, G.P.; Tomasetto, C.; Diemunsch, P.; Akladios, C. Antitumor effects of lidocaine on human breast cancer cells: An in vitro and in vivo experimental trial. Anticancer Res. 2018, 38, 95-105. [PubMed]

95. Johnson, M.Z.; Crowley, P.D.; Foley, A.G.; Xue, C.; Connolly, C.; Gallagher, H.C.; Buggy, D.J. Effect of perioperative lidocaine on metastasis after sevoflurane or ketamine-xylazine anaesthesia for breast tumour resection in a murine model. Br. J. Anaesth. 2018, 121, 76-85. [CrossRef] [PubMed]

96. Freeman, J.; Crowley, P.D.; Foley, A.G.; Gallagher, H.C.; Iwasaki, M.; Ma, D.; Buggy, D.J. Effect of perioperative lidocaine, propofol and steroids on pulmonary metastasis in a murine model of breast cancer surgery. Cancers 2019, 11, 613. [CrossRef] [PubMed]

97. Freeman, J.; Crowley, P.D.; Foley, A.G.; Gallagher, H.C.; Iwasaki, M.; Ma, D.; Buggy, D.J. Effect of perioperative lidocaine and cisplatin on metastasis in a murine model of breast cancer surgery. Anticancer Res. 2018, 38, 5599-5606. [CrossRef] [PubMed]

98. Xing, W.; Chen, D.T.; Pan, J.H.; Chen, Y.H.; Yan, Y.; Li, Q.; Xue, R.F.; Yuan, Y.F.; Zeng, W.A. Lidocaine induces apoptosis and suppresses tumor growth in human hepatocellular carcinoma cells in vitro and in a xenograft model in vivo. Anesthesiology 2017, 126, 868-881. [CrossRef] 
99. Tada, M.; Imazeki, F.; Fukai, K.; Sakamoto, A.; Arai, M.; Mikata, R.; Tokuhisa, T.; Yokosuka, O. Procaine inhibits the proliferation and DNA methylation in human hepatoma cells. Hepatol. Int. 2007, 1, 355-364. [CrossRef]

100. Fraser, S.P.; Foo, I.; Djamgoz, M.B.A. Local anaesthetic use in cancer surgery and disease recurrence: Role of voltage-gated sodium channels? Br. J. Anaesth. 2014, 113, 899-902. [CrossRef]

101. Kim, R. Anesthetic technique and cancer recurrence in oncologic surgery: Unraveling the puzzle. Cancer Metastasis Rev. 2017, 36, 159-177. [CrossRef]

102. Grandhi, R.K.; Perona, B. Mechanisms of action by which local anesthetics reduce cancer recurrence: A systematic review. Pain Medicine 2019. [Epub ahead of print]. [CrossRef]

103. Exadaktylos, A.K.; Buggy, D.J.; Moriarty, D.C.; Mascha, E.; Sessler, D.I. Can anesthetic technique for primary breast cancer surgery affect recurrence or metastasis? Anesthesiology 2006, 105, 660-664. [CrossRef] [PubMed]

104. Biki, B.; Mascha, E.; Moriarty, D.C.; Fitzpatrick, J.M.; Sessler, D.I.; Buggy, D.J. Anesthetic technique for radical prostatectomy surgery affects cancer recurrence: A retrospective analysis. Anesthesiology 2008, 109, 180-187. [CrossRef] [PubMed]

105. Kao, L.T.; Huang, C.; Lin, H.C.; Huang, C.Y. Antiarrhythmic drug usage and prostate cancer: A population-based cohort study. Asian J. Androl. 2018, 20, 37-42. [CrossRef] [PubMed]

106. Fairhurst, C.; Watt, I.; Martin, F.; Bland, M.; Brackenbury, W.J. Sodium channel-inhibiting drugs and survival of breast, colon and prostate cancer: A population-based study. Sci. Rep. 2015, 5, 16758. [CrossRef]

107. Fairhurst, C.; Martin, F.; Watt, I.; Doran, T.; Bland, M.; Brackenbury, W.J. Sodium channel-inhibiting drugs and cancer survival: Protocol for a cohort study using the CPRD primary care database. BMJ Open 2016, 6, e011661. [CrossRef]

108. Takada, M.; Fujimoto, M.; Motomura, H.; Hosomi, K. Inverse association between sodium channel-blocking antiepileptic drug use and cancer: Data mining of spontaneous reporting and claims databases. Int. J. Med. Sci. 2016, 13, 48-59. [CrossRef]

109. Walker, A.J.; Card, T.; Bates, T.E.; Muir, K. Tricyclic antidepressants and the incidence of certain cancers: A study using the GPRD. Br. J. Cancer 2011, 104, 193-197. [CrossRef]

110. Reddy, J.P.; Dawood, S.; Mitchell, M.; Debeb, B.G.; Bloom, E.; Gonzalez-Angulo, A.M.; Sulman, E.P.; Buchholz, T.A.; Woodward, W.A. Antiepileptic drug use improves overall survival in breast cancer patients with brain metastases in the setting of whole brain radiotherapy. Radiother. Oncol. 2015, 117, 308-314. [CrossRef]

111. Minotti, G. Pharmacology at work for cardio-oncology: Ranolazine to treat early cardiotoxicity induced by antitumor drugs. J. Pharmacol. Exp. Ther. 2013, 346, 343-349. [CrossRef]

112. Menna, P.; Calabrese, V.; Armento, G.; Annibali, O.; Greco, C.; Salvatorelli, E.; Marchesi, F.; Reggiardo, G.; Minotti, G. Pharmacology of cardio-oncology: Chronotropic and lusitropic effects of B-type natriuretic peptide in cancer patients with early diastolic dysfunction induced by anthracycline or nonanthracycline chemotherapy. J. Pharmacol. Exp. Ther. 2018, 366, 158-168. [CrossRef]

113. Benhaim, L.; Gerger, A.; Bohanes, P.; Paez, D.; Wakatsuki, T.; Yang, D. Gender-specific profiling in SCN1A polymorphisms and time-to-recurrence in patients with stage II/III colorectal cancer treated with adjuvant 5-fluoruracil chemotherapy. Pharmacogenomics J. 2014, 14, 135-141. [CrossRef] [PubMed]

114. Koltai, T. Voltage-gated sodium channel as a target for metastatic risk reduction with re-purposed drugs. F1000Research 2015, 4, 297. [CrossRef] [PubMed]

115. Wang, J.; Lu, Z.; Wu, C.; Li, Y.; Kong, Y.; Zhou, R.; Shi, K.; Guo, J.; Li, N.; Liu, J.; et al. Evaluation of the anticancer and anti-metastasis effects of novel synthetic sodium channel blockers in prostate cancer cells in vitro and in vivo. Prostate 2019, 79, 62-72. [CrossRef] [PubMed]

116. Brackenbury, W.J.; Djamgoz, M.B.A. Activity-dependent regulation of voltage-gated $\mathrm{Na}^{+}$channel expression in Mat-LyLu rat prostate cancer cell line. J. Physiol. 2006, 573, 343-356. [CrossRef] [PubMed]

(C) 2019 by the authors. Licensee MDPI, Basel, Switzerland. This article is an open access article distributed under the terms and conditions of the Creative Commons Attribution (CC BY) license (http://creativecommons.org/licenses/by/4.0/). 